\title{
Review and analysis of historical leakages from storage salt caverns wells
}

\author{
Pierre Bérest ${ }^{1, *}$, Arnaud Réveillère $^{2}$, David Evans $^{3}$, and Markus Stöwer ${ }^{4}$ \\ ${ }^{1}$ Laboratoire de Mécanique des Solides, Ecole Polytechnique, route de Saclay, 91128 Palaiseau, France \\ ${ }^{2}$ Geostock SAS, 2 rue des Martinets, 92500 Rueil-Malmaison, France \\ ${ }^{3}$ British Geological Survey, Nicker Hill, Keyworth, Nottingham NG12 5GG, England \\ ${ }^{4}$ UGS, Berliner Chaussee 2, 15749 Mittenwalde, Germany
}

Received: 19 September 2018 / Accepted: 29 November 2018

\begin{abstract}
Twelve incidents involving well casing and/or cement leaks in the salt caverns storage industry are described. These incidents occurred at the following storage sites: Eminence salt dome, Mississippi; Elk City, Oklahoma; Conway, Kansas; Yoder, Kansas; Mont Belvieu, Texas; Teutschenthal/Bad Lauchstädt, Germany; Clute, Texas; Mineola, Texas; Hutchinson, Kansas; Magnolia, Louisiana; Boling, Texas; Epe, Germany. Mechanisms leading to a casing leak and consequences are discussed. In most cases, a breach in a steel casing occurred at a depth where a single casing was isolating the stored product from the geological formations. The origin of the breach was due in most cases to poor welding/screwing conditions and corrosion, or excessive deformation of the rock formation. In this, the age of the well is often influential. In many cases, the leak path does not open directly at ground level; fugitive hydrocarbons first escape and accumulate in the subsurface prior to migrating through shallower horizons and escaping at ground surface. A pressure differential between hydrocarbons in the borehole and fluids in the rock mass favours fast leak rates. A wellhead pressure drop often is observed, even when the stored product is natural gas. The incidents described suggest that thorough monitoring (tightness tests) and a correct well design would lessen considerably the probability of a casing leak occurring.
\end{abstract}

\section{Introduction}

Prompted in part by projects related to carbon dioxide $\left(\mathrm{CO}_{2}\right)$ sequestration in which long-term tightness is crucial, there has been an increasing interest in the tightness of hydrocarbon (oil and gas) storage wells. In addition, high profile incidents, such as the 2015 Aliso Canyon blow-out, in California, have raised public awareness. The Aliso Canyon incident involved a massive gas leak from a depleted reservoir natural gas storage facility, the cause of which was a failure of the production tubing in a production well at around $2577 \mathrm{~m}(8450 \mathrm{ft})$ and consecutive leak from the well at a shallower depth (around $134 \mathrm{~m}$, or $440 \mathrm{ft}$; California Council on Science and Technology, 2018).

This paper focuses on hydrocarbon storage facilities using salt caverns, access to which in most cases is through a single well or, more rarely, through a number of wells. These wells are of similar design and construction to those used in the oil and gas industry. Salt caverns are almost perfectly tight and for this reason, as in most pressure vessels, the tightness problem is with the "piping" connecting the

\footnotetext{
* Corresponding author: pierre.berest@polytechnique.edu
}

cavern to surface, i.e., the completion (casing and tubing) and cementation of the wells.

Research and innovation on cementation have been ongoing since the early days of oil and gas production. However, challenging hurdles are still being faced. The effects of a better cement quality, of better cementing procedures or of more stringent regulations cannot be easily assessed, through simple and unequivocal criteria; in case of an incident or accident, the post mortem analysis is difficult as the origin of the leak is several hundreds or even thousands of metres below ground level. Drawing experience from real life takes time. One possible approach is based upon epidemiological principles, i.e., the statistical analysis of the largest number of cases and identification of correlations.

In a study of data for 315000 oil, gas and injection wells held by EUB, the regulatory agency in Alberta, Canada, Watson and Bachu (2007) discussed the results of two mandatory tests for wells, which have been required since 1995. The tests, undertaken within 60 days of drilling rig release and prior to well abandonment, are the Surface Casing Vent Flow (SCVF) test, and the Gas Migration (GM) test, which provides at least a first indication of well tightness. The paper focused on abandoned rather than active wells. These results are relative to tests performed at ground level 
and there is a risk, as for any statistical analysis, that the relation between causes and consequences remains ambiguous. Data analysis shows that there is a correlation between SCVF/GM results and oil price (with higher price comes the incentive to drill more wells, or more difficult wells, although equipment and skilled workforce are scarcer), geographic location and technology or regulatory changes. Additional influential factors are wellbore deviation, well type (drilled and abandoned wells have leakage occurrence rates smaller than cased and abandoned wells) abandonment method (wells in which a cement plug was placed across completed intervals has better results than bridge-plugged wells). Low cement top and exposed casings were found to be the most important indicator for SCVF/GM poor results.

Nicot (2009) surveyed abandoned oil and gas wells in the Texas Gulf Coast, drawing a list of factors, which are favourable for long-term tightness. The abandonment year is of special significance, as innovations were progressively introduced: Use of centralizers (1930), caliper surveys (1940), tagging of the cement plug, introduction of improved cement additives adapted to temperature, pressure, and chemical-specific conditions (1940), improvement of the quality of material used in well construction and abandonment. Nicot also outlines the promulgation of both specific plugging instructions by the Texas RailRoad Commission (In 1934, the RRC promulgated specific plugging instructions, and did so again in 1967.) and the Drinking Water Act, publication of API national standards (starting 1953), increased scrutiny by the State (after 1983) and certification of plugging operators (1997). Nicot points out that problems lie in the plugging/abandonment performance rather than in the quality of the material used.

In a survey of new gas wells in the US, Miyazaki (2009) suggested that up to $10 \%$ of the wells leaked. More specific to natural gas storages, Marlow (1989) undertook a survey covering some 6953 wells operated by twenty American Gas Association member companies. He mentions that:

"Tests show that even when the most up-to-date cement types and techniques are used, leakage can and will occur in a significant number of cases" (p. 1151).

The number of wells with a known operation lifetime duration until the leakage was detected was $426(6 \%)$, among which $77 \%$ leaked in less than 30 days (it is likely that they were rapidly repaired). Leakages at greater than 10 injection/withdrawal cycles occurred in only $2.6 \%$ of cases. The only statistically significant correlating variables are depth and bottom-hole pressure. Wells that leak tend to be deeper $(>4500 \mathrm{ft}$, or $1375 \mathrm{~m})$ and have higher pressures (>3000 psig, or $21 \mathrm{MPa})$.

In this paper a different approach is adopted. The paper draws on a report prepared by Réveillère et al. (2017) for the Solution Mining Institute (SMRI), representing a collaborative effort to gather and explain all wellhead failure, overfilling, or casing leaks incidents in the salt caverns storage industry; provided that public information was available, reliable and precise enough to gain a satisfactory understanding of the event. This analysis builds on 12 cases,

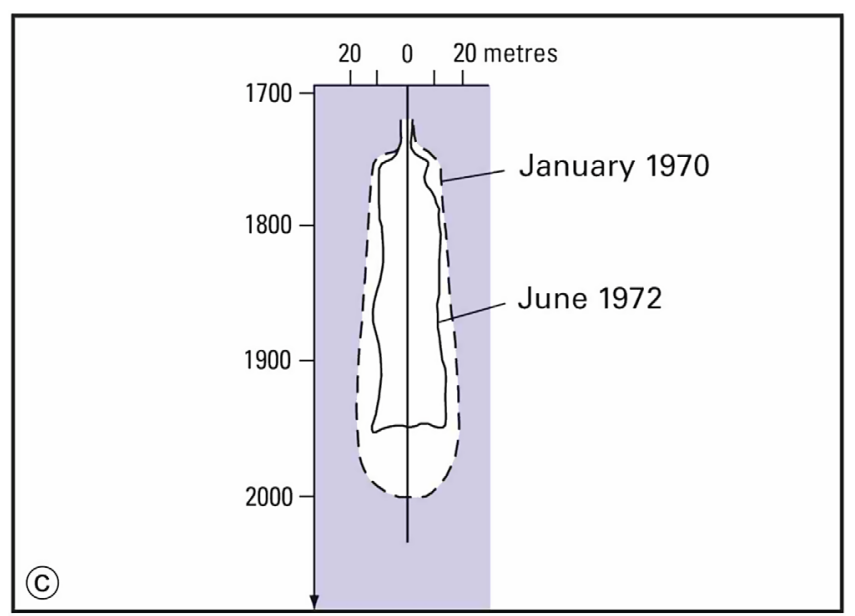

Fig. 1. Extent of salt creep and decrease in cavern size for Eminence Cavern \#1, as determined from cavern sonar surveys in 1970 and 1972. Based upon and redrawn from Allen (1972); Baar (1977); Coates et al. (1981); Bérest and Brouard (2003).

whereas the SMRI report detailed 21, in order to focus our analysis on casing leaks incidents (overfilling and wellhead failure are not considered in this paper). Cases which were not considered in the SMRI report imply breaches at the cavern walls, operational problems or surface piping failure. Additionally, two cases in the SMRI report - Conway and Yoder, Kansas - were merged in the present article. Hence the fact that 11 cases are presented, instead of 21 in the SMRI report.

The twelve cases of loss of tightness in salt caverns due to a leak through or along the cemented casing are described briefly in the first part of this paper. The second part, draws general lessons learned from these cases.

\section{Case histories}

\subsection{Eminence salt dome, Mississippi, 1970, 2004 and 2010-2011}

The Eminence salt dome is located $20 \mathrm{~km}$ (12 miles) northwest of Hattiesburg, Mississippi. The top of the salt is between 730 and $743 \mathrm{~m}(2400-2440 \mathrm{ft})$; it is overlain by a 150-m thick cap-rock of limestone and anhydrite. In 1991, this natural gas storage site comprised seven caverns. Caverns \#1-\#4 were certificated in the early 1970's and caverns 5, 6 and 7 in 1991. These caverns are especially deep, from $1725 \mathrm{~m}$ to $2000 \mathrm{~m}$ in the case of Cavern \#1 (Fig. 1). For those wells drilled in the 1970s, a $30^{\prime \prime}$ surface casing was set and cemented at $50 \mathrm{ft}$. A $28^{\prime \prime}$ hole was then drilled to $2700 \mathrm{ft}(823 \mathrm{~m})$ and a $20^{\prime \prime}$ OD cemented casing set, and the last cemented casing shoe, diameter $13 \%{ }^{\prime \prime}$, was at $1737 \mathrm{~m}$ (5700 ft) depth (Allen, 1971, 1972). Cavern \#1 was filled with gas at a $7 \mathrm{MPa}(1000 \mathrm{psi})$ pressure over a period of 2 months, after which it was increased to $28 \mathrm{MPa}$ (or $4000 \mathrm{psi}$; geostatic stress at cavern depth is 38-45 MPa). After a second pressure cycle, the "cavity bottom was at $1953 \mathrm{~m}$ (6408 ft), showing a loss of $46 \mathrm{~m}$ (152 ft) in about 
two years" (Baar, 1977; Coates et al., 1981) and cavern volume loss was $40 \%$ (Fig. 1). Once the problem was recognised, reduced losses were achieved through various measures, including maintaining a higher minimum pressure over extended time periods and less dewatering.

In 2004, Cavern \#4 well casing failed at a depth of $1639.5 \mathrm{~m}$ (5379 ft; Wellinghoff et al., 2013), i.e., a few dozens of feet above cavern roof. The company took Cavern \#4 out of service, filling it with water and shutting it in. On December 26, 2010, a large, unexpected pressure drop of $2.5 \mathrm{MPa}(357 \mathrm{psi})$ in one minute was detected in Cavern $\# 3$. The initial response to the leak was to flow $\sim 8.65 \mathrm{mcm}$ (306 MMcf) of gas into the pipeline system. Another gas leak from the wellhead of Cavern \#3 was accompanied by water shooting into the air from on-site water wells. On January 4, 2011, the company began flaring gas from Cavern \#3, until its production tubing became clogged with debris. Gas was also escaping from the ground around the wellhead of Cavern \#1. A large cave-in occurred, sealing off the flow. The company began drilling monitoring wells in the surrounding freshwater zones. By January 24, 2011, the decision was made to take Caverns \#1 and \#3 out of service. Later, a leak to the caprock was detected in Cavern \#7 and maximum operating pressure was lowered from $24.8 \mathrm{MPa}$ to $19.1 \mathrm{MPa}$ (3600 psi-2775 psi).

Investigations revealed that leakage in Cavern \#3 well likely arose through salt creep leading to overstretching of the casings above the cavern, where displacements due to creep closure were especially intense (Wellinghoff et al., 2013). These excessive strains led to damage of steel casings and/or steel-cement and cement-rock interfaces, as a result of which, gas migrated up the well to the cap-rock and ultimately to surface.

\subsection{Elk City, Oklahoma, 1973}

On February 23, 1973, the Oklahoma Geological Survey was informed that a central crater about $10 \mathrm{~m}$ by $15 \mathrm{~m}$ (30 ft by $50 \mathrm{ft}$ ) by $6 \mathrm{~m}$ (20 ft) deep, plus $20 \mathrm{~m}-50 \mathrm{~m}$ $(160 \mathrm{ft}-360 \mathrm{ft})$-long pressure cracks radiating from the crater, had appeared in level grassland, about $8 \mathrm{~km}$ ( 5 miles) south of Elk City, Oklahoma. Siltstone blocks of 20-45 kg (50-100 pounds) were thrown as far as $23 \mathrm{~m}$ ( $75 \mathrm{ft}$ ) away, and several 30-ton boulders were lifted to an upright posi-

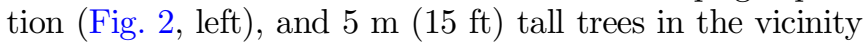
were tilted $45^{\circ}$. On March 1, 1973, gas samples were taken at the blow-out site. Analyses revealed 1\% total hydrocarbons, of which $75 \%$ was propane, a result excluding any natural origin. A leak from a propane salt storage cavern leached out from the upper part of the Permian Blaine formation was suspected. Several investigations and tests were undertaken at that site. A 13-hour observation period with the cavern maintained at constant halmostatic pressure was performed (i.e., with the inner tubing filled with saturated brine and opened at the surface). This test found a 30-gal/day $(5 \mathrm{~L} / \mathrm{h})$ apparent leak in the cavern (such a test is not fully conclusive as phenomena other than a leak can explain such an outflow). The storage cavern was emptied, with the propane being displaced from the cavern by brine on March 28. The two inner strings were retrieved and checked for flaws (Fig. 3). A cement-bond survey was run to assess cementing around the $10-3^{3 / 1}$ casing string. The survey demonstrated that the lower $60 \mathrm{~m}(200 \mathrm{ft})$, from about $341 \mathrm{~m}$ to $411 \mathrm{~m}(1120 \mathrm{ft}-1347 \mathrm{ft})$, in which a special resin cement had been used, was well bonded and that the upper $341 \mathrm{~m}(1120 \mathrm{ft})$ was poorly bonded. This strongly suggested that the leak was between $35.5 \mathrm{~m}$ and $340 \mathrm{~m}$, a zone in which the well was equipped with a single cemented casing (instead of two casings above $35.5 \mathrm{~m}$ ). As illustrated in Figure 3, liquefied gas would have leaked through a weak point in the well casing, migrated upwards in the poorly cemented annulus until it reached the Doxey shales. From there it would have migrated laterally to the blow-out site $700 \mathrm{~m}$ away from the wellhead and at $23 \mathrm{~m}$ lower elevation. The liquid LPG pressure would have decrease along the migration, triggering LPG vaporization at some point. The mechanical energy liberated by the vaporization generated the crater and cracks observed at the surface.

Both retrieved strings were then run back into the well with a packer added for isolating the $7^{\prime \prime} \times 10^{34^{\prime \prime}}$ annulus at $365 \mathrm{~m}$ (1197 ft). This annulus was filled with inert water and tested for leaks (Fig. 3). No leak was detected and neither did a pressure test on the cavern prove any leakage. The storage well was returned to service on April 23, 1973. There were no later reported leakages similar to the one that led to the blow-out, suggesting that the breach depth was located above $365 \mathrm{~m}$ depth, a zone now covered by two casings and a monitoring annulus.

\subsection{Conway-Yoder cavern field (Hutchinson salt formation), Kansas, 1980 and 2000}

Over 600 solution-mined salt storage caverns are located in Kansas. Nearly $50 \%$ of these are near Conway, a small town in eastern Kansas, where underground storage of Natural Gas Liquids (NGLs) began in 1951. Evidence of fugitive NGLs was known as early as 1956 (Ratigan et al., 2002). Propane was detected in several operators and domestic wells, ultimately leading to the relocation of residents and demolition of the properties.

The Hutchinson Salt Member of the Permian Wellington Formation from which the storage caverns were

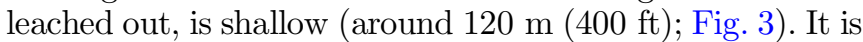
overlain by two impervious shale formations (Ninnescah and Wellington shale formations), above which lies the Quaternary Equus Beds Aquifer, a source of potable water. The eastern boundary of the Hutchinson Salt Member is a dissolution boundary (Fig. 4).

In December 2000, fugitive NGLs were encountered in a recently drilled cathodic protection at the Williams Conway Underground East (CUE) storage facility, which includes 71 caverns. Within a $1.6 \mathrm{~km}$ (1-mile) radius of this well, all wells (water, oil, observation) were investigated. NGLs were encountered in two more wells near brine recovery wells. The 71 operating wells were evaluated through pressure monitoring and temperature logs. As of March 15, 2002 , nearly all the wells have been evaluated and none have been found to be a contributor to the fugitive NL occurrence. Cement bond logs run in the wells revealed that casing cement-bonds were poor. 


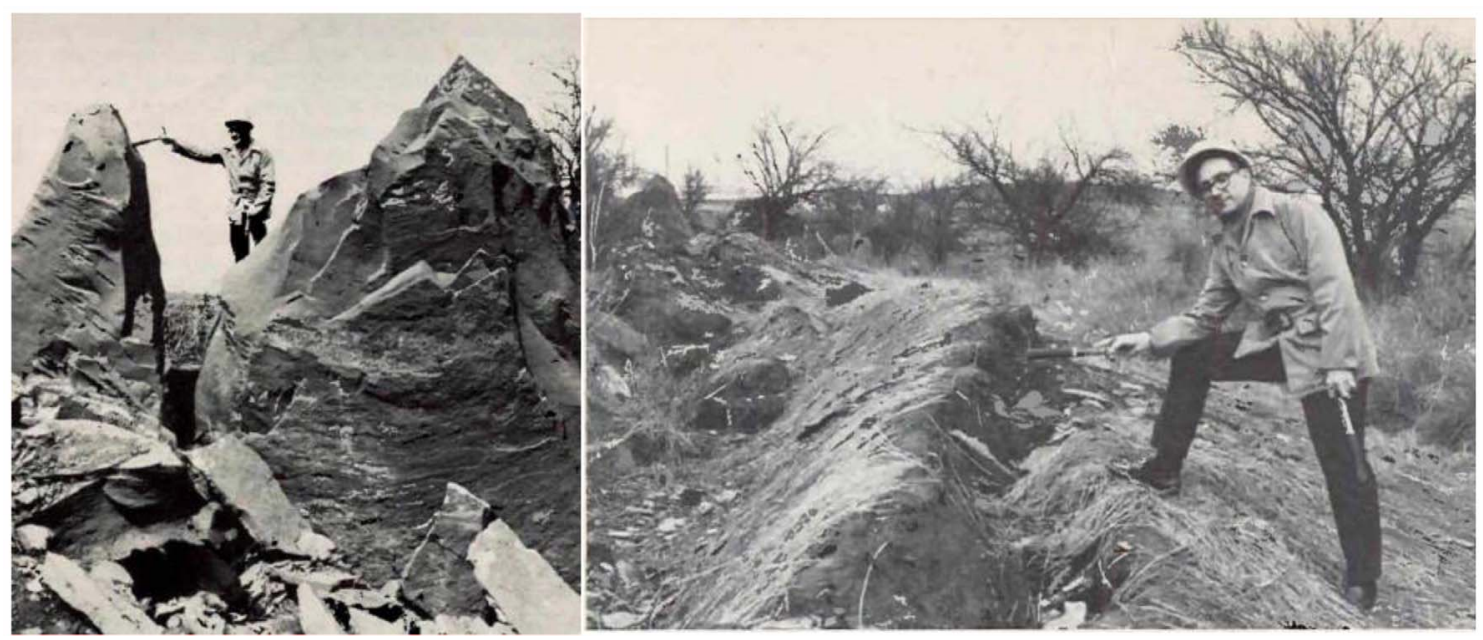

Fig. 2. Central crater (left, from Fay, 1973a) and one of the pressure cracks (right, from Fay, 1973b) discovered on February 23, 1973.

A similar incident occurred on June 30, 1980 near Yoder, Kansas, $9.7 \mathrm{~km}$ (6 miles) south of Hutchinson and $48 \mathrm{~km}$ (30 miles) south of Conway. A propane blow-out occurred along the shoulder of a county road. Bryson (1980) reported:

"Groundwater and sand were blown fifteen to twenty feet into the air. Within twenty-four hours, the pressure of the propane in hole had abated. Within a week, the surface of the water in the blowout conduit was placid, however propane vapors continued to rise up through clay and silt surrounding the hole".

In 2004, Johnson and Hoffine presented an update of the Conway investigations:

"The results of the investigation indicated a plume of NGL located east of the Brine Production Test Well Willems No. 1. Geophysical logging of the Brine Production Test Well Willems No. 1 and adjacent Brine Production Well indicated poor cement bond along the casings. Subsequent abandonment of the Brine Production Well Willems No. 1 and recompletion of the Brine Production Test Well Willems No. 1 have resulted in a rapid and significant decrease in the concentration of NGLs in the adjacent shallow Monitoring Well CUE01-6S".

\subsection{Mont Belvieu, Texas, 1980}

This accident occurred in 1980 at Barber's Hill, near Mont Belvieu, Texas, where a salt dome is home to 134 solutionmined caverns (and 135 wells) used primarily for Liquefied Petroleum Gas (LPG) storage and distribution and for brine production (Ratigan, 2009).

On September 17, 1980 a pressure drop was recorded at the wellhead of one of the salt caverns containing LPG.
On October 3, a spark from an electrical appliance ignited gas (70\% ethane, $30 \%$ propane) that had accumulated in the foundation of a house in the area, causing an explosion; there were no casualties. The cavern in which the pressure had dropped was emptied and filled with brine. In the days that followed, gas appeared haphazardly around the area, and 50 families had to be evacuated. Holes were drilled into the water table above the salt to find and vent the gas. Investigations proved (Fig. 5) that gas had leaked through a breach in the well casing - which was 22 years old - at caprock depth. Depths to caprock and to salt are $100 \mathrm{~m}$

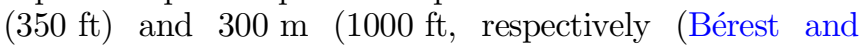
Brouard, 2003; Pirkle, 1986).

\subsection{Teutschenthal/Bad Lauchstädt, Germany, 1988}

The Teutschenthal/Bad Lauchstädt storage site is located $\cong 40-\mathrm{km}$ (26 miles) west of Leipzig, central Germany (Fig. 6), Arnold et al. (2010). Bedded rock salt (halite) deposits lie at a depth of $500 \mathrm{~m}-1000 \mathrm{~m}$ (1500-3000 ft), with the thickness of the halite increasing to the SE, from less than $50 \mathrm{~m}$ to more than $500 \mathrm{~m}$. The overburden comprises $300 \mathrm{~m}(1000 \mathrm{ft})$ of argillaceous rocks overlain by a $110 \mathrm{~m}(360 \mathrm{ft})$ thickness of an alternating sandstone and mudstone sequence (Fig. 7).

The well Ug Lt 5/71 was drilled and completed in 1971, within which the last cemented $11-3 / 8^{\prime \prime}$ casing shoe was set

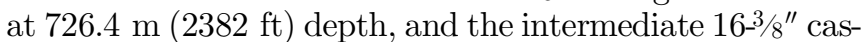
ing shoe depth at $92.1 \mathrm{~m}$ (302 ft) (Fig. 7). The cavern, with a volume of $40000 \mathrm{~m}^{3}$, was used to store ethylene. On March 29, 1988, a drop in pressure in the ethylene annulus of cavern Ug Lt $5 / 71$ from $7.5 \mathrm{MPa}$ to $4 \mathrm{MPa}$ was observed. One hour later, the first eruption of an ethylene - water mixture took place $50 \mathrm{~m}(165 \mathrm{ft})$ away from the well and was followed by additional eruptions in a NorthWest direction and $250 \mathrm{~m}(800 \mathrm{ft})$ southward, close to the neighboring cavern Ug Lt 6/71 (Fig. 6). Elongated chimneys formed, from ejected debris and partly pulsating ethylene-water fountains, aligned along parallel WNW-ESE 
Pre-incident well

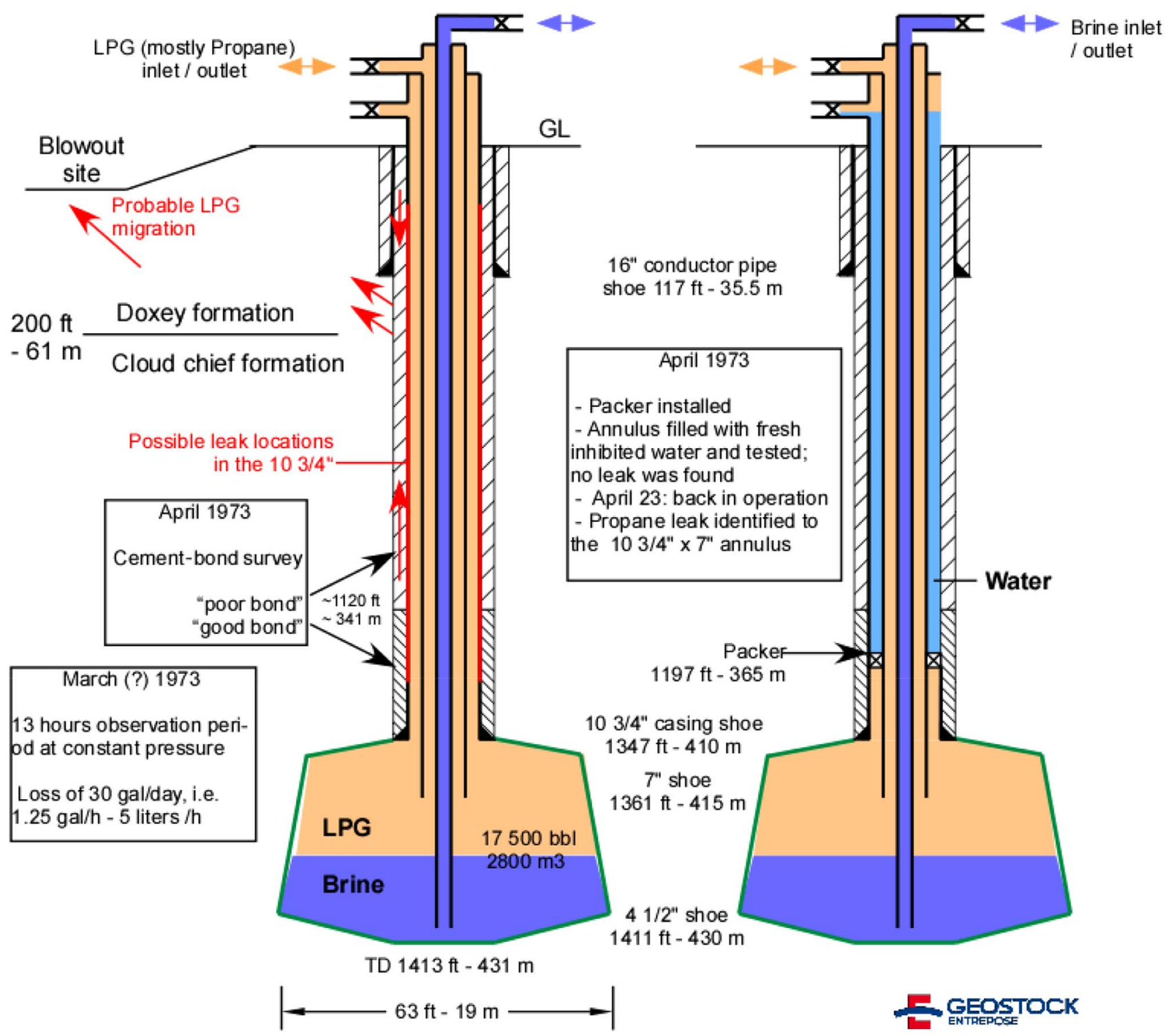

Fig. 3. State of the well before and after the incident, probable leakpath (in red) and summary of the main investigations.

lines. The emission of ethylene continued for several days until an estimated $60-80 \%$ of the cavern volume was released. An area of $8 \mathrm{~km}^{2}$ was evacuated.

Ethylene outflow decreased rapidly. Immediately after the start of the eruption elevation surveys revealed an NW-SE trending ellipsoid uplift of $0.2 \mathrm{~m}(0.7 \mathrm{ft})$. Fractures and crevasses, displaced concrete road pads, and fractures were found in a building at the crest of this uplift. This enabled an estimate of uplift prior to the blow-outs as around $0.5 \mathrm{~m}(1.7 \mathrm{ft})$.

Subsequent downhole surveys found a damaged connection to the $11-3 / 4^{\prime \prime}$ casing at a depth of $111.8 \mathrm{~m}$, from which ethylene escaped and accumulated in a sandstone layer between 100 and $140 \mathrm{~m}$ depth. The sandstone lies below a 25-m thick impervious layer, which was uplifted and led to overstretching and failure of the $11-3 / 4^{\prime \prime}$ casing, ultimately resulting in a massive release of ethylene on March 29th.

\subsection{Clute, Texas, 1988}

This storage cavern facility was constructed in the Stratton Ridge Salt Dome about $1.6 \mathrm{~km}$ (1 mile) NE of Clute in south Brazoria County, $25 \mathrm{~km}$ (15 miles) SSW of Houston, Texas. Several hundred oil and gas wells drilled across the salt diapir have established its shape and structure. The caprock is several hundred feet thick, comprising limestones, gypsum and anhydrite beds and the diapir shows an unusual geometry, including a large structural depression in the eastern third of the dome. This and the features and problems associated with the caprock, which are most likely caused by active salt movement, indicate that the internal salt structure is complex and still evolving. The internal structure and fabric of the salt is thus likely to influence construction and operation of any storage caverns (Lord et al., 2006). 


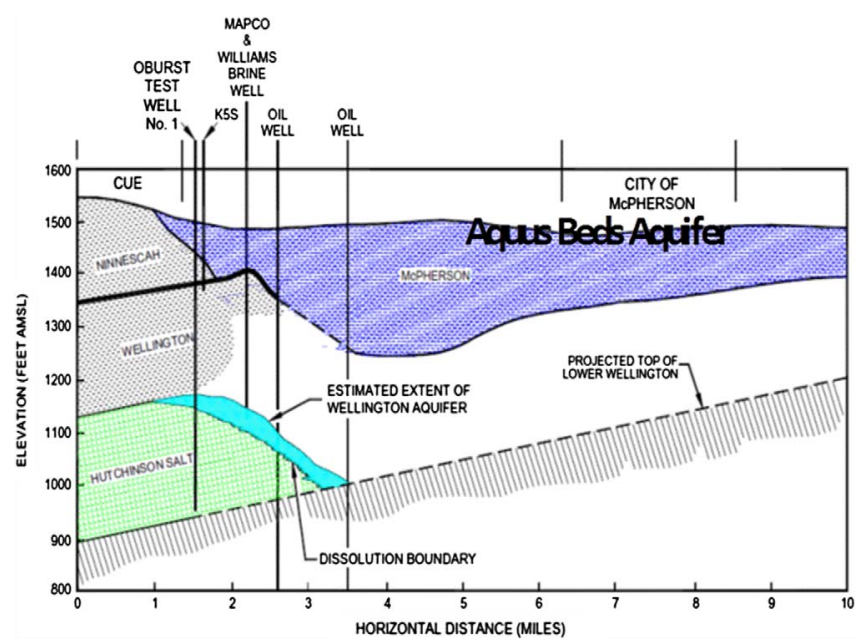

Fig. 4. West-East cross-section of the Williams-CUE Facility (After Ratigan et al., 2002).

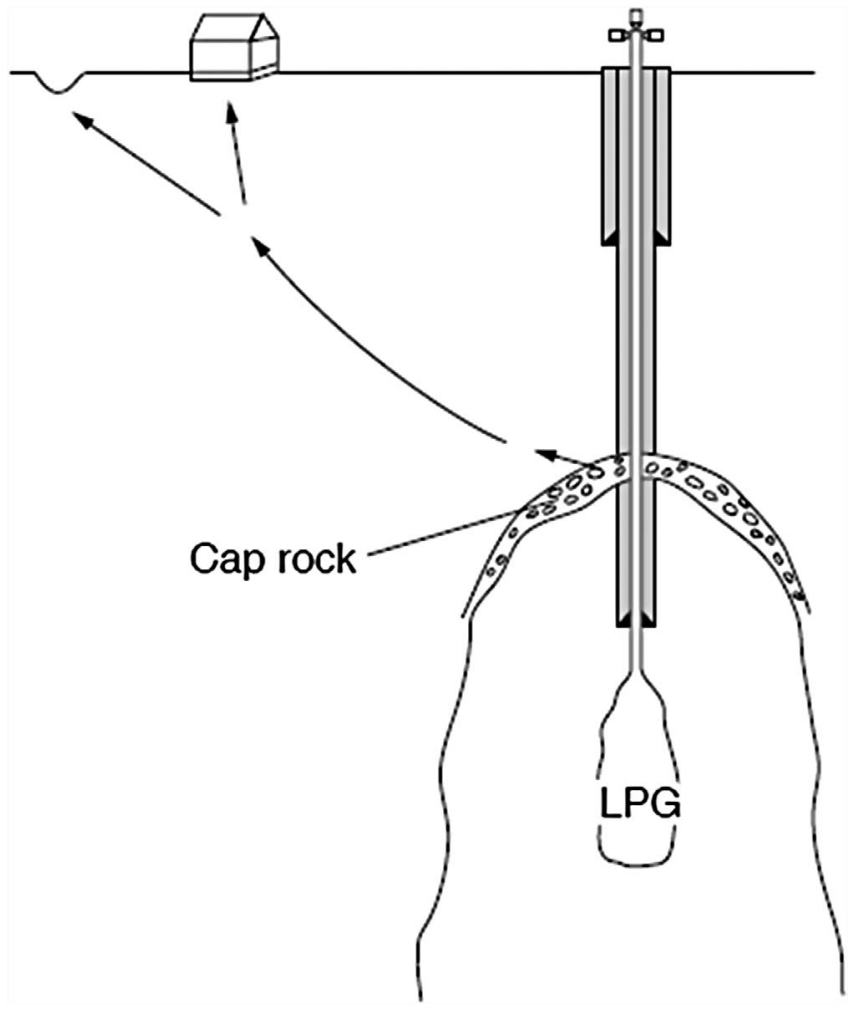

Fig. 5. Conceptual sketch of an LPG leak from the Mont Belvieu cavern (from Bérest and Brouard, 2003).

On December 27, 1988, company officials advised the Rail Road Commission of Texas that they were aware ethylene had been lost from a storage cavern. By December 30 , it was assessed that the loss amounted to $1850 \mathrm{~m}^{3}$ (0.5 million gallons). Water wells in the area were tested but found no contamination (Toth, 1989a). It was decided

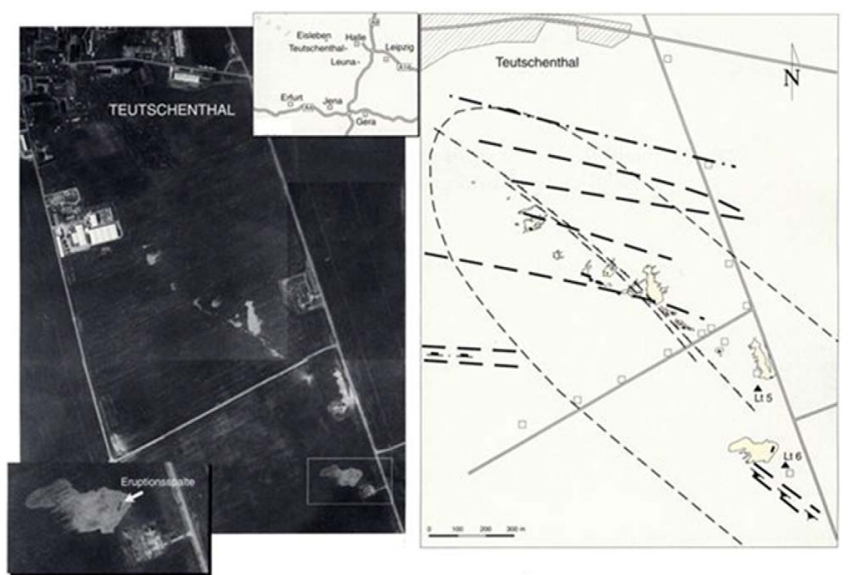

Fig. 6. Aerial photo of the site on April 3rd 1988 showing location of the well, the settlement area of Teutschenthal, alignment of eruptions and close up of main eruption fracture. Right side showing fault zones and area of uplift as dashed lines and elevation measuring points as squares. Based upon and modified from Katzung et al. (1996).

to drill an exploratory well near the site to try and discover the whereabouts of the escaped ethylene and perhaps attempt recovery of some (Toth, 1989b, 1990). The first test well was drilled on March 19th 1989 and the fugitive ethylene was immediately located. The escaped product was flared off and continued to be so until at least April 1990 (Toth, 1990).

Company officials said the casing failure could have been caused by movement in the salt formation with product having escaped at around $396 \mathrm{~m}(1300 \mathrm{ft})$ depth.

\subsection{Mineola, Texas, 2000}

This incident occurred in 2000, at the Mineola Storage Terminal about $145 \mathrm{~km}$ (90 miles) east of Dallas, Texas (Warren, 2006). Its cause and how the resultant fire was extinguished was described by Gebhardt et al. (2001). The facility had two storage caverns the wells to which were originally drilled as oil producers in the late 1950s. One cavern, the volume of which was $49000 \mathrm{~m}^{3}$ (13 million gallons) of propane, suffered loss of product. Well completion

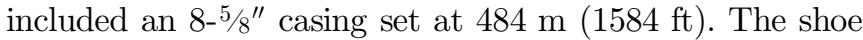
of the $5-1 / 2^{\prime \prime}$ tubing string was $720 \mathrm{~m}(2400 \mathrm{ft})$ deep, $30 \mathrm{~m}$ $(100 \mathrm{ft})$ above the cavern bottom; it seems that undersaturated water, rather than brine, was used as an injection fluid. The cavern well developed a casing leak at an undetermined depth. According to Gebhardt et al., 2001, the "initial" theory was that injection of undersaturated water led to dissolution and thinning of the salt pillar (wall) between the caverns; a leak was created when a workover was run on the second cavern, where nitrogen was being used in the workover to ensure that there was no LPG in the tubing. The pressure induced in the workover well caused fracturing in the salt pillar. In this theory, the pressure surge was transmitted to the cavern in LPG causing a breach in its well casing. Propane escaped from the well and 


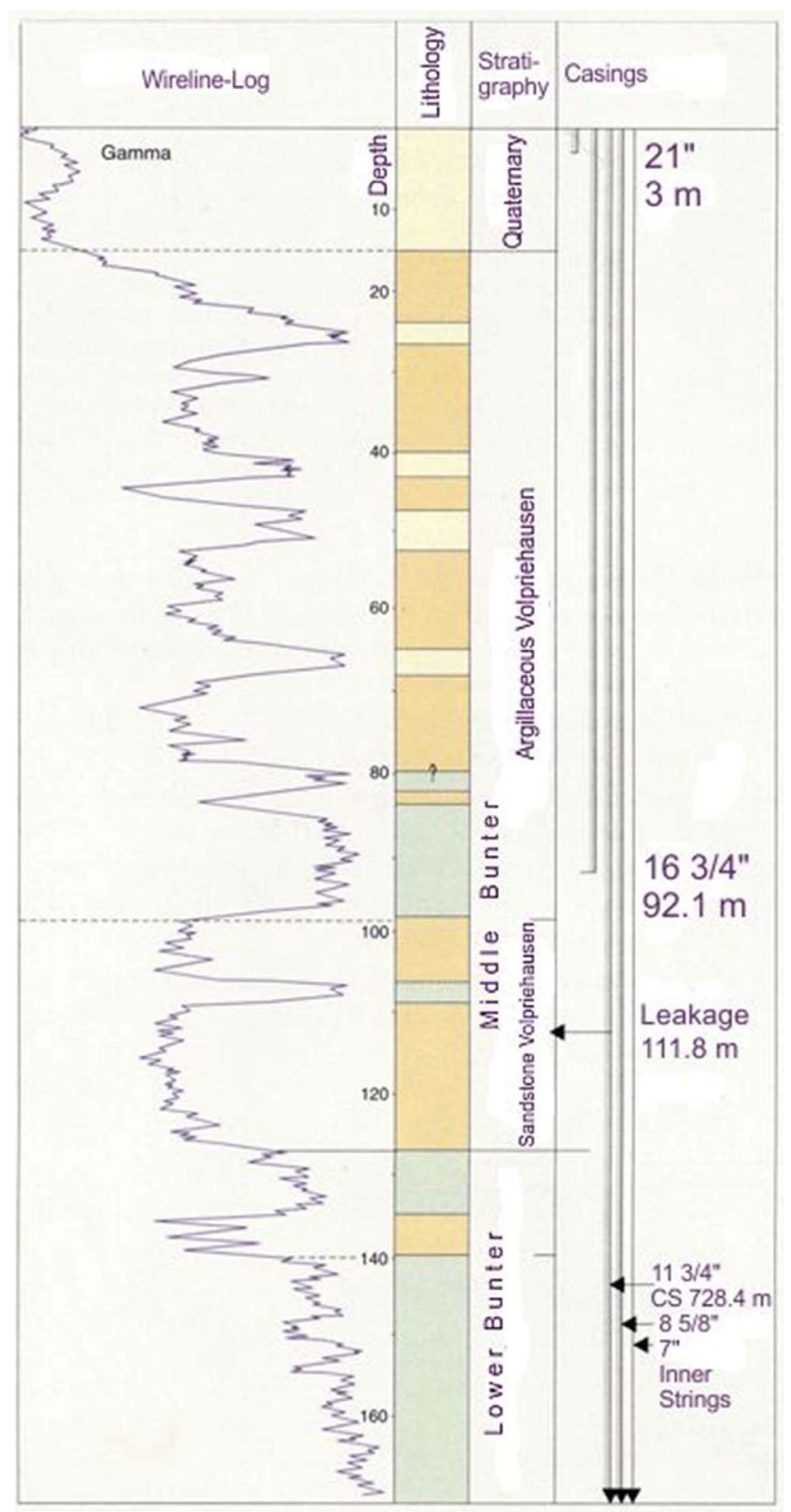

Fig. 7. Casing program and top-hole geology of Ug Lt $5 / 71$. Based upon and modified from Katzung et al. (1996).

migrated upwards, eventually escaping through surface soils to the atmosphere. It collected in low-lying areas around the terminal and surrounding forest and found an ignition source. The water-bearing shallow water sand was filled with LPG. A water well used to supply water for cavern leaching located approximately $50 \mathrm{ft}(15 \mathrm{~m})$ from the product withdrawal well was first to ignite and burn. This was followed by the cavern wellhead. Propane escaped through the soil up to $30 \mathrm{~m}(100 \mathrm{ft})$ from the well itself. Firefighters inferred from the behaviour of the fire that the casing leak was at shallow depth. Considerable efforts were required to extinguish the fire.

\subsection{Hutchinson, Kansas, 2001}

On January 17, 2001, at 10:45 am, a sudden release of natural gas burst from the ground under a store and a neighboring shop in downtown Hutchinson, a town with 40000 inhabitants in Kansas. Within minutes, the building was ablaze. During the afternoon of the same day, eight brine and natural-gas geysers began bubbling up, $3-5 \mathrm{~km}$ (2-3 miles) east of the downtown fire, some reaching $10-\mathrm{m}$ (30-ft) in height, two of the geysers igniting. The next day, natural gas coming up from such a long-forgotten brine well exploded beneath a mobile home, killing two people.

Also on January 17, 15 min after the first downtown blast and $13 \mathrm{~km}$ (8 miles) northwest of downtown Hutchinson, technicians from the Yaggy natural-gas storage recorded a gas-pressure drop of $0.7 \mathrm{MPa}$ (100 psi) in the S-1 salt cavern, whose casing shoe was $239 \mathrm{~m}$ $(794 \mathrm{ft})$ below ground level. The underground storage facility was developed in the 1980s to hold propane. The owner became bankrupt, and the wells were plugged by partially filling them with cement. In the early 1990s the site was converted to a natural-gas storage. A link between the pressure drop and the events in Hutchinson was suspected immediately, even though the distance between the storage and the downtown geysers [10-12 km (7-8 miles)] set a puzzling geological and reservoir engineering problem. A plug was set at the bottom of the S-1 well and a downhole video run. This revealed a large curved slice in the casing at a depth of about $180 \mathrm{~m}(585 \mathrm{ft})$. It was suspected that various metal objects, including a steel casing coupler, had been dropped down the well when the former storage was abandoned. During the well re-opening, when the cement and cast-iron plugs were drilled, the system composed of the drill bit and dropped metal objects cut a slice "like a kitchen knife cutting into a can" in the $9^{\prime \prime}(23-\mathrm{cm})$ casing of the S-1 cavern at about the depth [179 m (595 ft)] of the later leak. Gas moved vertically up the outside of the casing from the breach until it reached a fractured gypsiferous/dolomitic horizon ( $\mathrm{G}$ on Fig. 8) at the top of the Wellington Shale Formation. At this point the gas migrated laterally updip to the east towards Hutchinson, remaining trapped between two impermeable shale layers, where it encountered the abandoned brine wells. Most of these were only cased down to a shallow aquifer. Clear evidence of the existence of multiple independent channels within the dolomite layer is suggested by the occurrence of a dozen geysers during the 24-h period following the first blow-out. The geysers appeared in the west and then progressively eastwards, and vented the accumulation of gas under the city, until no further gas eruptions occurred. In the following weeks, a number of seismic reflection lines were acquired to try to locate the gas migration path, and 36 venting wells were drilled. Only eight of them hit gas, supporting the view that migration of gas to surface occurred along narrow pathways or channels within the dolomite layer (Allison, 2001).

After 1997, the State had authorized a 17.5\% maximum pressure increase, raising the maximum pressure at the casing shoe (239 $\mathrm{m}$ to $794 \mathrm{ft}$ deep) to $4.78 \mathrm{MPa}$ (693 psi). This additional storage capacity remained largely unused for years on Cavern S1. Early in January 2001, gas was 
Cross section showing Hutchinson salt member in relation to other geologic strata

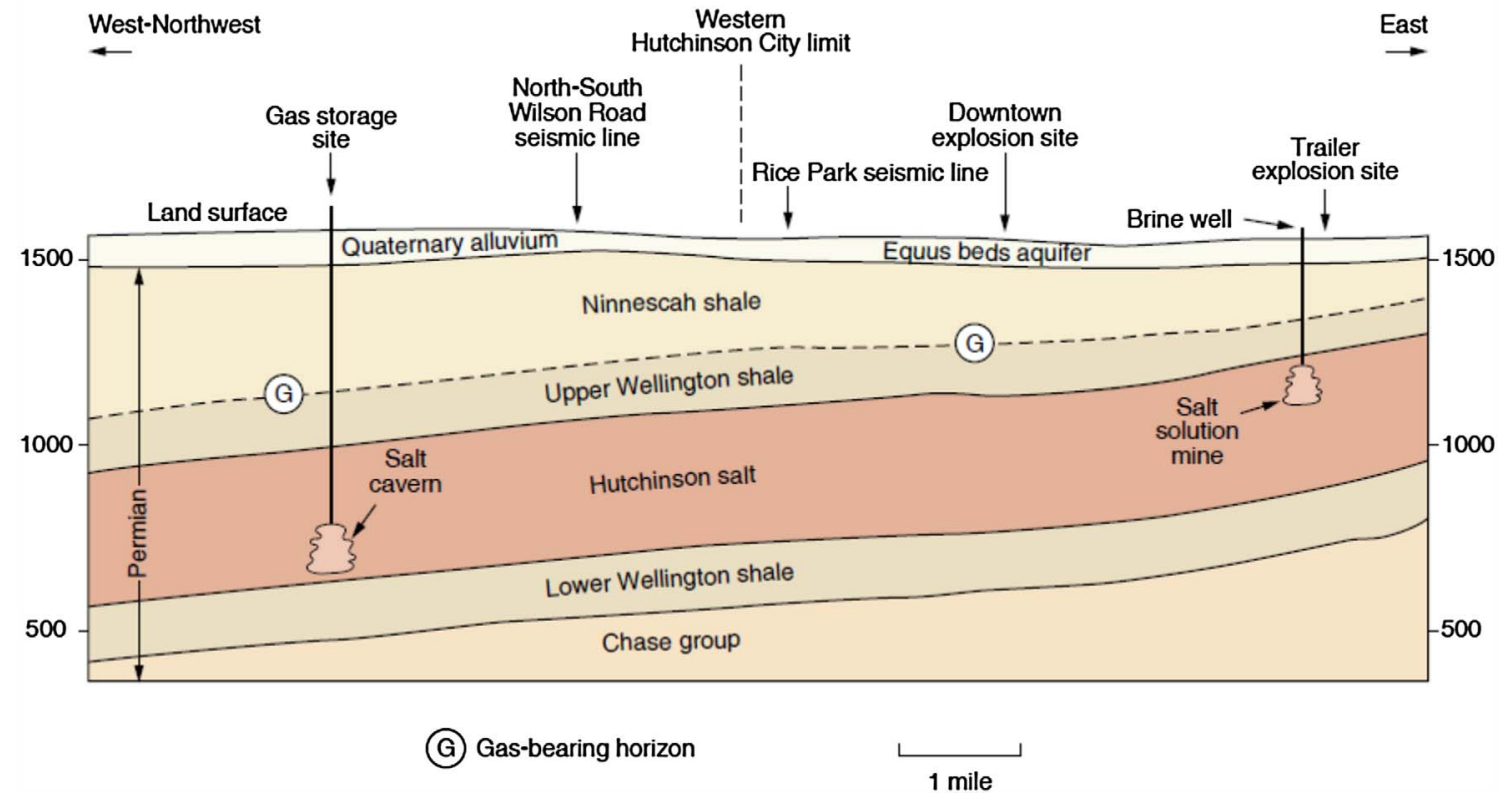

Fig. 8. Hutchinson leak pathway. Quaternary alluvions are composed of sands and gravels, 50-ft thick. Elevations are in feet. Below are the Permian Ninnescah Shale, the Upper Wellington Shale and the Hutchinson Salt member. The gas-bearing interval ranges from 270 -ft deep in the east side of the city to 400-ft deep several miles northwest of the city; the dip is $20 \mathrm{ft}$ per mile. Gas migrated through fractured dolomite layers (G-G). (Kansas Geological Survey Web Site, 2001).

injected and the pressure jumped from $2.9 \mathrm{MPa}(426 \mathrm{psi})$ to $4.76 \mathrm{MPa}(691 \mathrm{psi})$ at 6 a.m. on January 14 . The pressure gradient was then $2.66 \times 10^{-2} \mathrm{MPa} / \mathrm{m}(1.18 \mathrm{psi} / \mathrm{ft})$ at leak depth on January 14 and gas pressure was above the overburden pressure. The pressure began to drop at the wellhead, a move that, with hindsight, may be interpreted as a clear sign of increasing leak rate. The pressure build-up spread throughout the gas-filled fractured channels, ultimately reaching that of hydrostatic pressure beneath the Hutchinson area.

After the accident, poor regulation and, when compared to other states, the small number of inspection staff in Kansas state, were implicated by several experts (e.g., Ratigan, 2001). New sets of regulations were discussed and imposed (Johnson, 2002). These included mandatory double casing in wells, corrosion control, restrictions on well-conversion (salt caverns designed to store LPG could not be converted to store natural gas, and cavern wells that have been plugged cannot be reopened and reused), a maximum pressure gradient of $0.76 \mathrm{psi} / \mathrm{ft}\left(1.73 \times 10^{-2} \mathrm{MPa} / \mathrm{m}\right)$ at the production casing shoe, and new testing requirements (with a Mechanical Integrity Test (MIT) performed every 5 years).

\subsection{Magnolia, Louisiana, 2003}

The natural gas storage facility of Magnolia is located at Grand Bayou, Louisiana, where several other storage and brine production caverns are operational. Salt roof is $200 \mathrm{~m}(600 \mathrm{ft})$ deep. In 2003, the facility included Caverns \#13 and \#14, drilled in the 1970's. On November 1, operations started filling the caverns with natural gas.
On December 24, an underground gas leak led to the release of about $9.9 \mathrm{MNm}^{3}$ (0.35 billions $\left.\mathrm{ft}^{3}\right)$ in a matter of hours. The gas migrated to an adjacent aquifer and then to the atmosphere. On December 29, cavern operations were suspended and 30 residents were evacuated. The wells were plugged and 36 vent wells were installed in the aquifer over the salt dome, of which 17 collected or burned off gas. Downhole videos were run in the wells. Several theories were put forward to explain the gas leak from around $440 \mathrm{~m}$ (1450 ft) below the surface. Causes of the leak were considered to be: crushed casings (EIA, 2006), cracks in the casing (Edgar, 2005; Hopper, 2004), separation of three or four $13-3 / 8^{\prime \prime}$ casings connections permitting gas to leak behind the casing and then to the surface (Nations, 2005), or improper back-welding that resulted in cracks in the well casing (State of Louisiana, 2007). Video of Well \#13 is reported as showing cracks in the casing near a coupling; the well had been plugged at the point of the lowest crack, after which the leakage stopped, which pointed to the cracks as a possible cause of the leaks.

\subsection{Boling, Texas, 2005}

Four caverns had been solution-mined and filled with natural gas between 1980 and 1983 in the Boling Dome near Boling, Wharton County, Texas. Depth to the caprock is globally about $192 \mathrm{~m}(630 \mathrm{ft})$, and the top of the salt occurs at a depth of around $305 \mathrm{~m}(1000 \mathrm{ft})$. Cavern roof depths are between 1066 and $1083 \mathrm{~m}$ (3497 and $3553 \mathrm{ft}$ ), except for Cavern \#3, the roof of which is deeper by $45-60 \mathrm{~m}$ (150-200 ft). Apart from Cavern \#3, 11-3/8" casing shoe 
is close to the cavern roofs (0-18 $\mathrm{m}[0-59 \mathrm{ft}]$ above), which are flat (Fig. 9).

In the Fall of 2005, Cavern \#4 was nearly full. An abnormally fast pressure drop was observed, which was monitored over a period of several weeks. Temperature loggings found cold spots in Caverns \#1, \#2 and \#4, raising the possibility of a production casing leak not far above the cavern roof. During gas removal, the three caverns were filled with water.

Detailed investigations into the incident were undertaken, including running downhole video camera logs, which identified casing collar and coupling partings for over $100 \mathrm{~m}$ above the casing shoe depth (Fig. 10). The video log revealed that the casing had failed at eight different locations, always near or at a connection. Failure often was a circumferential fracture. The casing being dragged down after it fractured, up to $60 \mathrm{~cm}$ height of cement could be observed in between the two parts of the fractured casing.

Fracture shape, the absence of any failure in Cavern \#3 the chimney which was $60-\mathrm{m}$ in height, and flat roofs, strongly suggest that casings were overstretched above cavern roofs and experienced tensile failure. This was confirmed by numerical analyses, that clearly showed the cemented casings of Wells \#1, \#2 and \#4 were not able to accommodate the resulting large tensile salt strains, and their ultimate strength limit was exceeded (Fig. 11).

The well repair procedure for the three leaking wells

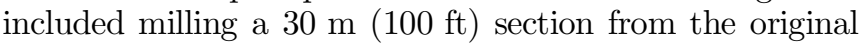
$11-3 / 8^{\prime \prime}$ casing and cementing a $10-3 / 4^{\prime \prime}$ welded liner. The new casing shoe, $30 \mathrm{~m}$ higher than the original one, was therefore in a zone where simulations suggest the strain induced by the salt creep should stay below the casings strength, thanks to this new $30 \mathrm{~m}$ long cavern neck.

\subsection{Epe, Germany, 2014}

At the Epe site, $80 \mathrm{~km}$ (5 miles) north of Dortmund, Germany, several dozens of salt caverns have been leachedout from a 200-400 m (656-1312 ft) thick sequence of halites overlain by clastic and argillaceous rocks; top of salt can be found at a $1000-\mathrm{m}(3281 \mathrm{ft})$ depth. The Epe S5 cavern is $147 \mathrm{~m}$ (482 ft) in height, with a diameter of $82 \mathrm{~m}(269 \mathrm{ft})$ and volume of approximately $450000 \mathrm{~m}^{3}$ (2.7 mbbls). In 1980, approximately $408000 \mathrm{~m}^{3}(2.45 \mathrm{mbbls})$ of oil were injected into storage. The cavern operated in brinecompensated mode, with brine injected or produced through a $7-5 / 8^{\prime \prime}$ string to displace the crude oil through the $11-3 / 4^{\prime \prime} \times$ $7-5 / 8^{\prime \prime}$ annulus. The last $11-3 / 4^{\prime \prime}$ casing is anchored at a $1086.8 \mathrm{~m}(3566 \mathrm{ft})$ depth and the penultimate $16^{\prime \prime}$ cemented casing at a $212 \mathrm{~m} \mathrm{(696} \mathrm{ft)} \mathrm{depth.} \mathrm{Typical} \mathrm{of} \mathrm{a} \mathrm{strategic} \mathrm{oil}$ reserve, it experienced only a small number of withdrawals or injections.

On February 23rd and 24th 2014, a pressure drop of $0.36 \mathrm{MPa}$ (52 psi) was recorded in the annular space of Cavern S5. The cavern was taken out of operation and a number of inspection runs were performed in the well. These did not indicate any evidence of a leakage. The mining authorities agreed to commence operation again on April 2nd 2014 with restrictions regarding the maximum pressure.

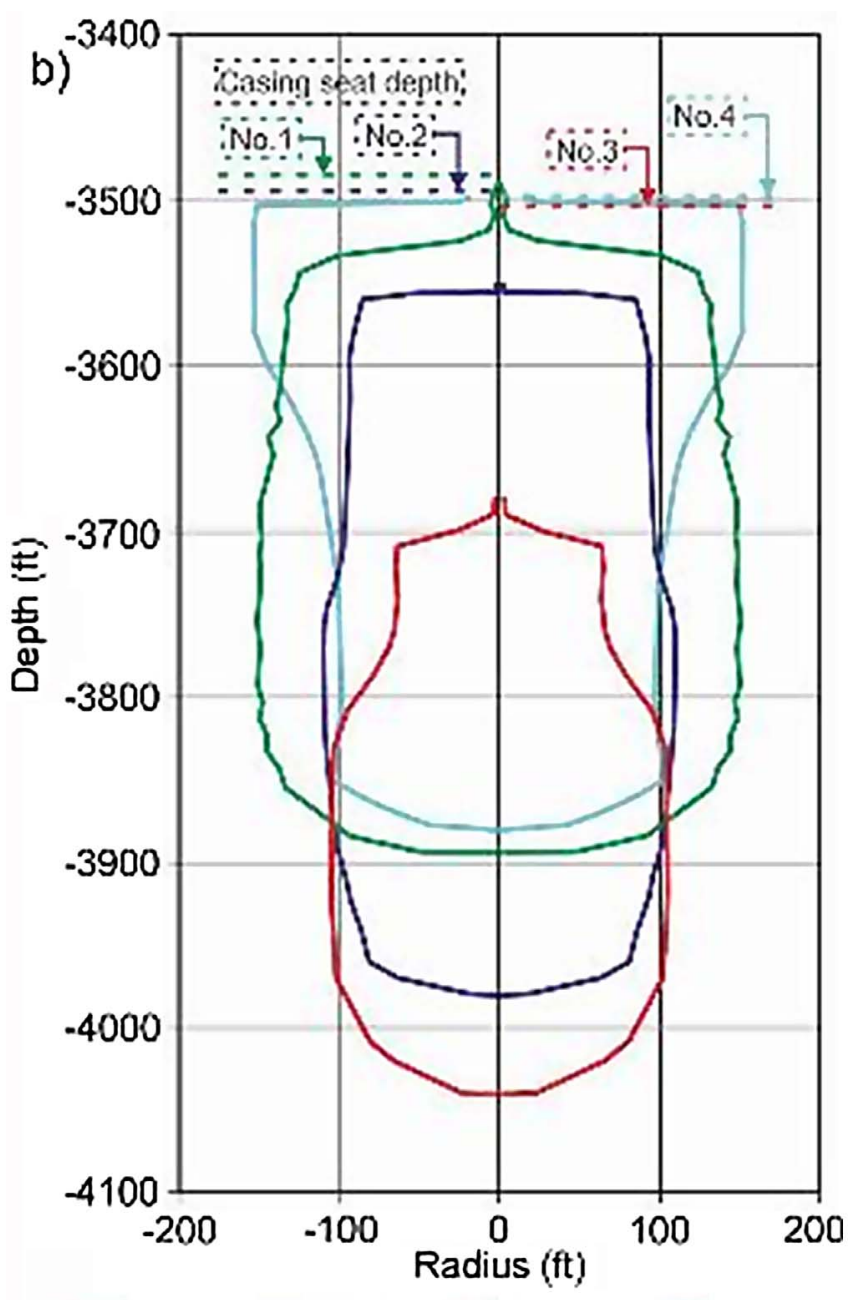

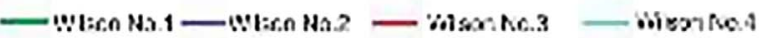

Fig. 9. General cross-sections of caverns, based on sonar data. From Osnes et al. (2007)

On April 12th 2014, an oil seep was discovered at surface in a meadow. On April 15th, two more spills developed close to a farm, inducing a family to leave their home for some days. After first analysis of the locations of the spills, it became clear that the origin of the crude oil was Cavern S5. The cavern was made safe and multiple efforts were undertaken to understand the reasons for the leakage, assess the extent of the leakage, minimize its impact and, ultimately, restore cavern integrity.

Investigations and computations suggested that cavern convergence, evidenced by subsidence measurements at ground level, caused movement of the rock mass (salt) surrounding Cavern S5, especially at a depth of $217 \mathrm{~m}(712 \mathrm{ft}$; Fig. 12). The calculated vertical strain at a depth of $200 \mathrm{~m}$ $(656 \mathrm{ft})$ is approx. $0.1-0.2 \mathrm{~mm} / \mathrm{m}$, enough to trigger a significant displacement on the casing connection at $217 \mathrm{~m}$ $(712 \mathrm{ft})$. Above $212 \mathrm{~m}$ ( $\sim 696 \mathrm{ft})$, the completion, including the $16^{\prime \prime}$ casing, is much stiffer and stronger than the onecasing section below and it was concluded that the first casing connection below the $16^{\prime \prime}$ casing shoe was a critical point for structural damage. 

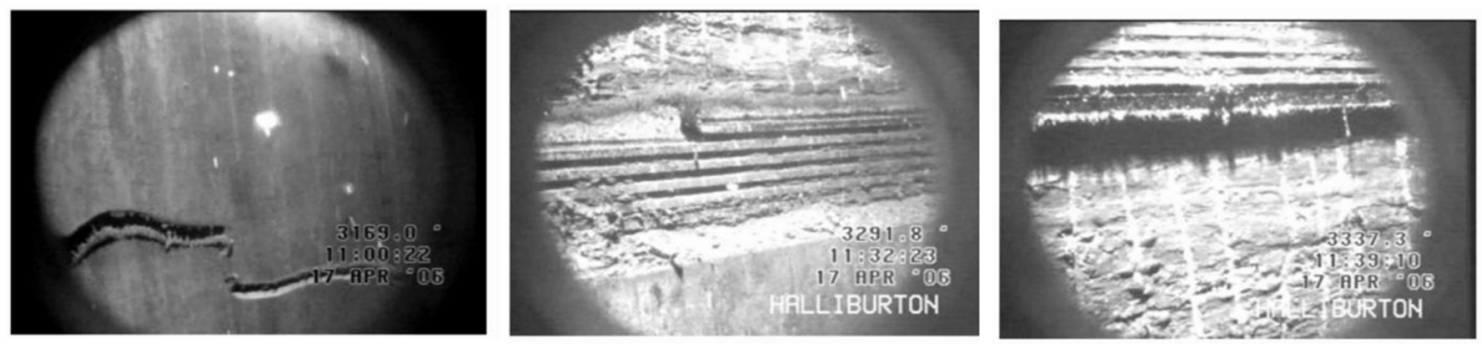

Fig. 10. Examples of failures detected by the video inspection. From left to right: Circumferential fracture of the pipe body, of the threaded coupling, and thread jump-out. From Osnes et al. (2007).

At a depth of $217 \mathrm{~m}$ (712 ft), crude oil pressure was 8.1 $\mathrm{MPa}$ and capillary entrance pressure of the enclosing argillaceous series (mudstones) was approximately $4.7 \mathrm{MPa}$ (682 psi). Pre-existing shear zones and fractures in the surrounding rocks re-opened, along which the crude oil migrated as the permeability of the matrix is too low for oil penetration. Upon reaching the base of the Quaternary series, the crude oil migrated into a shallow, groundwater aquifer and ultimately reached the surface.

As a result of this incident, and as is already the case in the Netherlands, it is expected that to prevent that kind of incident in future, the regulations for operating storage caverns in Germany will require a double barrier installation for all wells (Bezirksregierung Arnsberg, 2014; Coldewey and Wesche, 2015; Kukla and Urai, 2015).

\section{Analysis}

\subsection{Leaks main characteristics}

\subsection{Lessons drawn from incidents}

Tables 1-3 provide the main characteristics of 11 incidents, which can be described as leaks through the casing. We do not claim the list is comprehensive. The original work relied on material in the public domain and it is likely that other cases and incidents exist but are not in the public domain. These, it is thought, would include defects in cementation, defective welding or screwing which were detected early (during tests performed after drilling or after solutionmining was completed) and repaired; or the migration of fluids through the cemented annulus, which were collected at ground level and treated. Such incidents, which are part of routine operation and creation of a cavern, are not widely reported in the literature. The table is, however, likely to cover the most significant incidents in the history of storage salt caverns worldwide (except for ex-USSR, for which public information is scarce).

The featured incidents (casing leaks) are relatively few, when it is borne in mind that more than 2000 salt storage caverns have been operated successfully and without incident, sometimes for more than 50 years. Two casualties have arisen (at Hutchinson) and several hundred people have been evacuated during incidents. These are too many, however, the numbers are extremely small when compared to the toll resulting from above-ground tanks accidents that would be the alternative storage option for liquids and gas (Evans, 2007). From the perspective of safety, underground storage benefits from several intrinsic advantages (no oxygen is available underground; high fluid pressures are the normal state underground, sensitivity to terrorist activities or other acts of aggression is low).

However, lessons must, and can be, drawn to prevent further accidents.

\section{Factors influencing the occurrence of a casing leak}

The analysis of the leak mechanisms identified in the 11 cases previously analyzed enables to identify some common patterns. In the following the onset and nature of a breach (Sect. 4.1), the development of a leak (Sect. 4.2), consequences at ground level and monitoring-prevention are discussed (Sect. 4.3). These three successive steps are represented in Figure 13.

\subsection{Onset of a breach}

\subsubsection{Leak initiation}

In most incidents, a breach (and leakage) is created through a steel casing at a depth where the well completion comprises a single cemented casing ("single barrier"). It is noteworthy that in the oldest wells, the depth of the penultimate casing shoe was shallow, and a single casing formed more than $50 \%$ of the total length. In the accidents described here, depths of the two last cemented casings were $35.5 \mathrm{~m}$ and $410 \mathrm{~m}$ at Mineola; $212 \mathrm{~m}$ and $1086.6 \mathrm{~m}$ at Epe; $823 \mathrm{~m}$ and $1737 \mathrm{~m}$ at Eminence; $92.1 \mathrm{~m}$ and $728.4 \mathrm{~m}$ at Teutschenthal (Fig. 14).

The breach may result from physico-chemical phenomena (internal and external corrosion), or in faulty screwed or welded connection between two consecutive pipes. However, external mechanical phenomena may also contribute to the creation of a breach. At Hutchinson, a somewhat exceptional case, an LPG storage well on abandonment was plugged and cemented. When required for later natural gas storage, the well had been drilled-out. A slice was cut in the steel casing during drilling.

Deformation of the salt mass (or, more generally, the rock formation) is a more generic cause. Two basic cases 

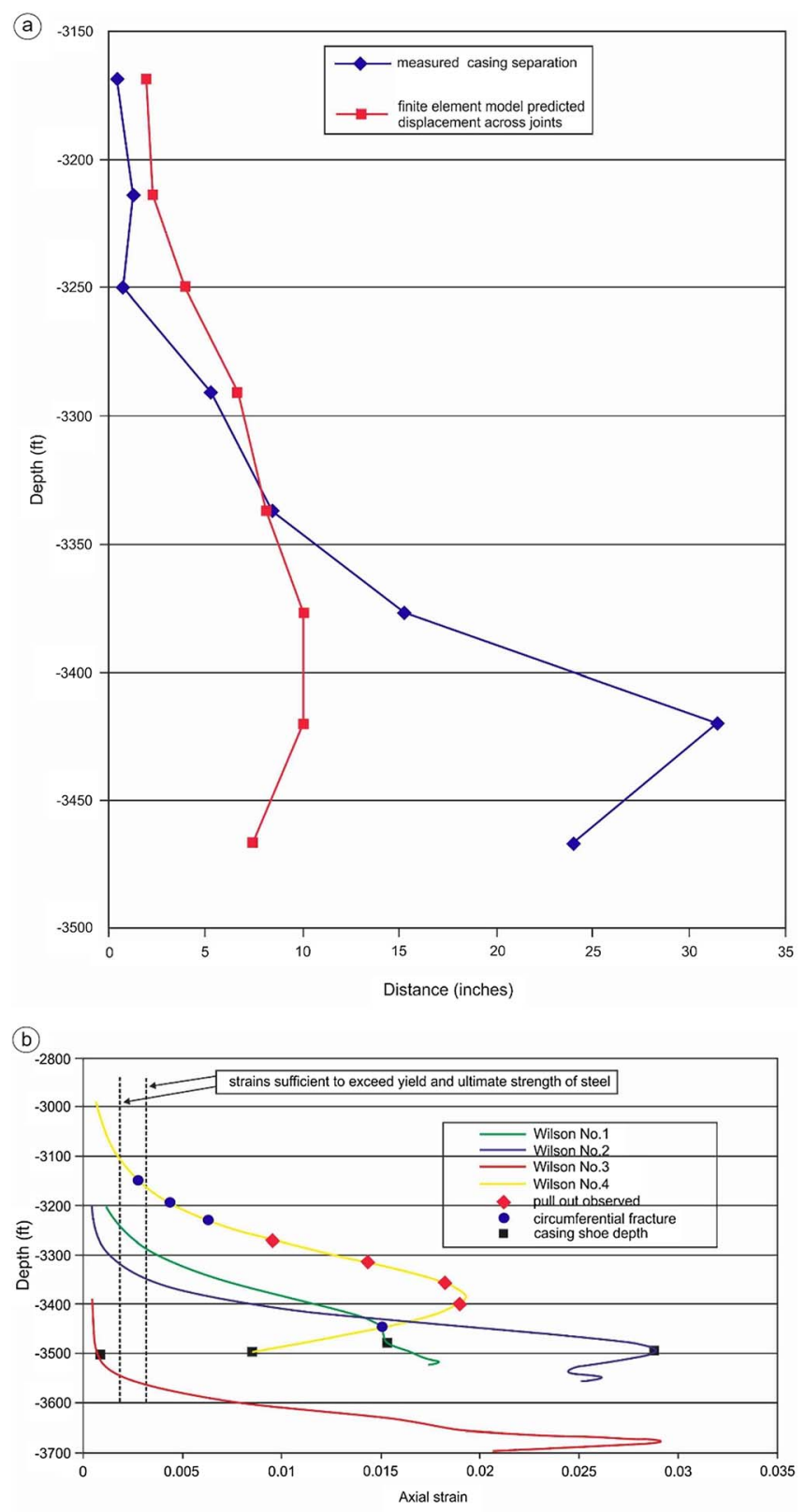

Fig. 11. Observed and modelled casing deformations (from Osnes et al., 2007). a) Comparison of measured casing separation and predicted relative displacements between casing connections from finite element modelling; b) vertical strains as a function of depth in the salt near the centre lines of the Wilson storage caverns predicted from finite element modelling.

can be distinguished, depending on whether the casing is subject to excessive tensile or shear stresses.

In the first case, the last cemented casing shoe is close to the cavern roof (the "chimney" or "neck" below the casing shoe is not very tall). In the case of Eminence, cavern creep closure was rapid in this region of the well, because the caverns were deep, and/or because cavern roof was flat, a shape that generates large vertical strains, as in the case of Boling wells $\# 1,2$ and 4 . In Boling well \#3 the last casing shoe was anchored much higher above the cavern roof and the well experienced no leak (Fig. 9). In both the Eminence and Boling cases, large vertical strains led to casing overstretching and failure.

To a certain extent, the Epe case also belongs to the tensile failure type, however overstretching took place at much shallower depth. Breach creation is believed to originate in a large overall subsidence, which was initiated by and as a result of cavern convergence. This led to a sharp contrast in vertical deformations above and below the penultimate casing shoe, where the breach appeared. At Teutschenthal, two stages were recognised in the leak development. The initial leak rate was slow, perhaps over many years, or even dozens of years, during which time gas accumulated in a 30-m thick layer whose thickness increased by half a metre; in this layer the casing, strongly bonded to the rock mass, became overstretched and at one point it experienced tensile failure, leading to the formation of a much larger "secondary" breach, which allowed higher leak rates. One hour later, ethylence and water mix blew out at ground surface.

In the second case, due to tectonic deformation inside a salt dome, large differential movements develop, including horizontal differential (shear) displacements between two levels, the mechanical properties to which are in sharp contrast (for instance, salt top and caprock). The casing, which is strongly bonded to each of these two levels, experiences shear failure (this is likely to have happened at Clute). This interpretation is confirmed by several incidents (the consequences of which were small) such as the failure of casings at caprock depth at the West-Hackberry oil storage facility (Sobolik and Ehgartner, 2012).

There is no well-documented example in which a leak clearly starts at the depth of the last-cemented casing shoe, which often is considered to be a weak point from the perspective of cavern tightness. For instance, at Boling, breach(es) were close to, but above the casing shoe point.

To summarize the main findings, two likely causes which do not exclude one another, and do not exclude a combination with other causes - appear. In all the cases, a breach is created in a zone where well completion includes a single casing. Except for the Hutchinson case (the breach was created when re-drilling an abandoned well), five cases are related to a structural cause: Eminence, Boling, Clute, Teutschenthal and Epe cases, with proven or suspected excess tensile stress experienced by the casings. In the Eminence, Boling, Clute and Epe cases, this is, or is suspected to be, due to salt creep dragging down the casings. In the Teutschenthal escape, this was due to a small leak that accumulated over a caprock, creating a local uplift. We note that phenomena are relatively slow to occur and if a tightness test had been conducted during commissioning of the caverns, it would not have detected a problem. Therefore, a relationship exists with the ages of the wells.

\subsubsection{Influence of well age}

Table 4 illustrates that leakage occurrences happen several dozens of years after well creation. This might be the time needed for a breach in the casing to occur through corrosion; or excessive strains, tensile and shear stresses to build 


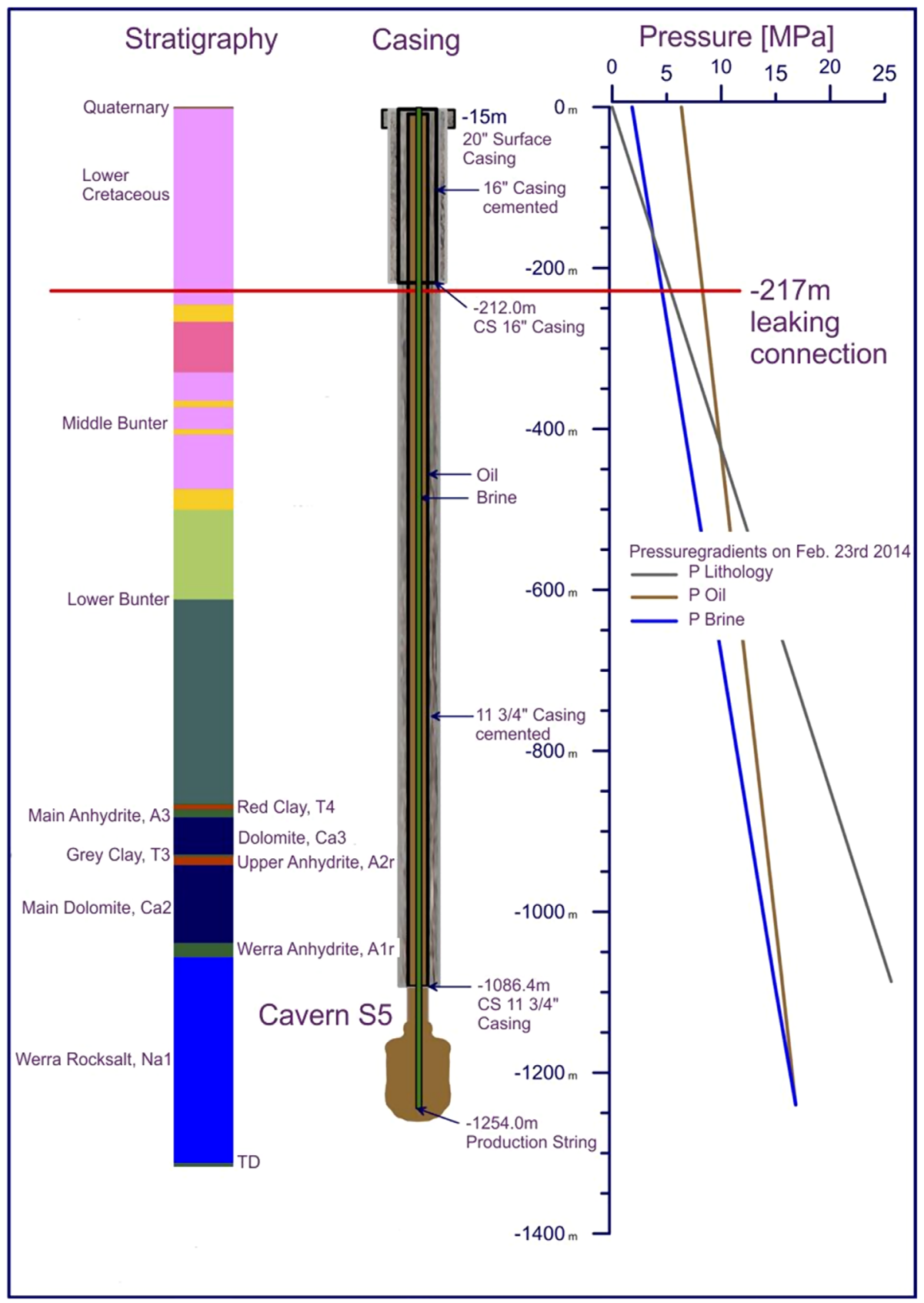

Fig. 12. Well scheme and pressure gradients of Epe S5 (Stöwer, in: Réveillère et al., 2017)

up through salt creep. In the US, the last incident occurred in Texas in 2005 (where, since 1993, a double casing anchored in the salt formation has been mandatory for new caverns) at Boling, which had only one casing anchored in the salt formation, and in 2001 in Kansas (where similar regulations were enforced in 2003 following the Hutchinson incident).

\subsection{Leak development}

In this section the factors which favour the development of a leak are explored.

\subsubsection{An intermediate outlet often is needed}

A leak can only develop from a breach in the casing when a pathway to an outlet exists, or is created. This outlet may be ground level, a sufficiently porous and permeable underground layer or structural zone (e.g., a fault or jointed rock mass). Conversely, where no receptor horizon exists, or when the cementing job was completely successful, leading to a low permeability and a high gas entry pressure, a breach in the casing does not result in a leak. This occurs when, at breach depth, the rock mass is tight or deforms plastically, tightening the bond between rock and the cement job. In this respect, rocksalt (or clays/shales) 
Table 1. The main characteristics of Elk City, Oklahoma; Conway-Yoder field, Kansas; Mt Belvieu, Texas; Mineola, Texas.

\begin{tabular}{|c|c|c|c|c|c|}
\hline & & Elk City, Oklahoma & $\begin{array}{c}\text { Conway-Yoder field, } \\
\text { Kansas }\end{array}$ & $\begin{array}{l}\text { Mt Belvieu, } \\
\text { Texas }\end{array}$ & $\begin{array}{l}\text { Mineola, } \\
\text { Texas }\end{array}$ \\
\hline \multirow{6}{*}{$\begin{array}{l}\text { Cavern } \\
\text { information }\end{array}$} & Commissioning & After 1954 & 600 caverns since 1951 & 1963 & End of 50's \\
\hline & $\begin{array}{l}\text { Incident date } \\
\text { (1st noticed) }\end{array}$ & February 1973 & $\begin{array}{l}\text { NGL detected in wells } \\
\text { 1956-2012; Propane } \\
\text { atmosphere eruptions } \\
\text { June } 30,1980\end{array}$ & $\begin{array}{l}9 / 17 / 1980 \\
\text { (pressure drop); } \\
\text { gas burst on } \\
10 / 3 / 1980\end{array}$ & 1995 \\
\hline & Geology & $\begin{array}{l}\text { Bedded salt Formation } \\
\text { Blaine, alternating } \\
\text { layers of salt, } \\
\text { anhydrite, shale's }\end{array}$ & $\begin{array}{l}\text { Bedded salt tight } \\
\text { overburden; located at } \\
\text { a dissolution boundary }\end{array}$ & $\begin{array}{l}\text { Domal salt } \\
\text { Pervious Caprock } \\
\text { Drill losses }\end{array}$ & Domal salt \\
\hline & Stored product & $\begin{array}{l}\text { LPG } \\
\text { (mainly propane) }\end{array}$ & Propane, or LPG & Ethane, propane & Propane \\
\hline & $\begin{array}{l}\text { Last cemented } \\
\text { casing shoe }\end{array}$ & $10^{3 / 4^{\prime \prime}}$ at $410 \mathrm{~m}$ & $\approx 200 \mathrm{~m}$ & & $85 / 8$ at $482 \mathrm{~m}$ \\
\hline & $\begin{array}{l}\text { Penultimate } \\
\text { cemented c.s. }\end{array}$ & $35.5 \mathrm{~m}$ & & & \\
\hline \multirow[t]{3}{*}{$\begin{array}{l}\text { Leak } \\
\text { mechanism }\end{array}$} & Breach depth & $\begin{array}{l}\text { Less than } 365 \text { m } \\
\text { deep }\end{array}$ & & & Shallow? \\
\hline & Pressure drop & & & On $09 / 17 / 80$ & \\
\hline & Mechanism & $\begin{array}{l}\text { A breach somewhere } \\
\text { between } 365 \mathrm{~m} \text { and } \\
35.5 \mathrm{~m} \text {, upward in the } \\
\text { cement, horizontal in } \\
\text { the Doxey Formation }\end{array}$ & $\begin{array}{l}\text { Gas leaking from } \\
\text { several faulty wells }\end{array}$ & $\begin{array}{l}\text { The leak was } \\
\text { likely to be at } \\
\text { caprock depth }\end{array}$ & $\begin{array}{l}\text { A breach in } \\
\text { the casing } \\
\text { originating } \\
\text { from a } \\
\text { pressure } \\
\text { surge in a } \\
\text { neighboring } \\
\text { cavern }\end{array}$ \\
\hline \multirow[t]{3}{*}{$\begin{array}{l}\text { Impact at } \\
\text { the surface }\end{array}$} & $\begin{array}{l}\text { Effects at ground } \\
\text { level }\end{array}$ & $\begin{array}{l}9 \times 15 \mathrm{~m}, 6 \mathrm{~m} \text { deep } \\
\text { crater }\end{array}$ & $\begin{array}{l}\text { Propane found in } \\
\text { shallow wells }\end{array}$ & $\begin{array}{l}\text { Explosion in a } \\
\text { cellar, gas is } \\
\text { found in shallow } \\
\text { waters }\end{array}$ & $\begin{array}{l}\text { Gas } \\
\text { occurrences } \\
\text { near the } \\
\text { wellhead }\end{array}$ \\
\hline & $\begin{array}{l}\text { Distance from } \\
\text { wellhead }\end{array}$ & $\begin{array}{l}700 \mathrm{~m}, 23 \mathrm{~m} \text { below } \\
\text { wellhead elevation }\end{array}$ & & & $\begin{array}{l}\text { In a } 30-\mathrm{m} \\
\text { radius around } \\
\text { the wellhead }\end{array}$ \\
\hline & $\begin{array}{l}\text { Evacuation/ } \\
\text { Casualties }\end{array}$ & & $\begin{array}{l}\text { Several families } \\
\text { relocated }\end{array}$ & $\begin{array}{l}50 \text { families } \\
\text { evacuated }\end{array}$ & \\
\hline \multirow[t]{2}{*}{$\begin{array}{l}\text { Emergency } \\
\text { resp. and } \\
\text { remediation }\end{array}$} & Measures taken & $\begin{array}{l}\text { Soil gas sampling } \\
\text { and analysis, storage } \\
\text { emptied, CBL run }\end{array}$ & $\begin{array}{l}\text { Analysis of geological } \\
\text { data, Temperature logs, } \\
\text { CBL, } 8 \text { monitoring } \\
\text { wells drilled, } \\
71 \text { operating wells } \\
\text { evaluated }\end{array}$ & $\begin{array}{l}\text { Cavern emptied, } \\
\text { wellbores tapped } \\
\text { in the shallow } \\
\text { aquifer layer to } \\
\text { vent gas }\end{array}$ & $\begin{array}{l}\text { Fire } \\
\text { extinguished }\end{array}$ \\
\hline & Remediation & $\begin{array}{l}\text { Water-filled annular } \\
\text { space, packer set } \\
\text { at } 365 \mathrm{~m}\end{array}$ & Brine wells abandoned & & \\
\hline
\end{tabular}


Table 2. The main characteristics of Hutchinson, Kansas; Epe, Germany; Magnolia, Louisiana.

\begin{tabular}{|c|c|c|c|c|}
\hline & & Hutchinson, Kansas & Epe, Germany & Magnolia, Louisiana \\
\hline \multirow[t]{6}{*}{$\begin{array}{l}\text { Cavern } \\
\text { information }\end{array}$} & Commissioning & $\begin{array}{l}\text { Drilled in the } 80 \text { 's, and } \\
\text { abandoned. Re-opened } \\
\text { and filled with natural } \\
\text { gas in the } 90 \text { 's }\end{array}$ & 1980 (Epe S5) & $\begin{array}{l}\text { Wells } 13-14 \text { drilled in } \\
\text { the } 70 \text { 's }\end{array}$ \\
\hline & $\begin{array}{l}\text { Incident date (1st } \\
\text { noticed) }\end{array}$ & January 19, 2001 & Feb 23, 2014 & Dec 24, 2003 \\
\hline & Geology & $\begin{array}{l}\text { Bedded salt, Overlain } \\
\text { by impermeable layers; } \\
\text { however, thin } \\
\text { subhorizontal fractured } \\
\text { layers between two shale } \\
\text { layers }\end{array}$ & $\begin{array}{l}\text { Bedded salt, } \\
\text { Zechstein (Z1), } \\
200-400 \mathrm{~m} \text { salt } \\
\text { layer, roof at } \\
1000 \mathrm{~m}, \text { overlain } \\
\text { by clastic and } \\
\text { argillaceous layers }\end{array}$ & $\begin{array}{l}\text { Domal salt } \\
\text { (Napoleonville dome), } \\
\text { salt roof at } 200 \mathrm{~m}(?)\end{array}$ \\
\hline & Stored product & Natural gas & Oil & Natural gas \\
\hline & $\begin{array}{l}\text { Last cemented casing } \\
\text { shoe }\end{array}$ & $9^{\prime \prime}$ at $238 \mathrm{~m}$ & $11-3 / 4^{\prime \prime}$ at $1086.8 \mathrm{~m}$ & $13-3 / 8^{\prime \prime}$ \\
\hline & $\begin{array}{l}\text { Penultimate cemented } \\
\text { c.s. }\end{array}$ & & $16^{\prime \prime}$ at $212 \mathrm{~m}$ & \\
\hline \multirow[t]{3}{*}{ Leak mechanism } & Breach depth & $180 \mathrm{~m}$ & $\approx 217 \mathrm{~m}$ & $\approx 440 \mathrm{~m}$ \\
\hline & Pressure drop & yes & $0.36 \mathrm{MPa}$ & \\
\hline & Mechanism & $\begin{array}{l}\text { Milling created a breach } \\
\text { when re-drilling a } \\
\text { cemented abandoned well. } \\
\text { Gas migration through } \\
\text { fractured channels to the } \\
\text { brine aquifer below } \\
\text { Hutchinson, and to } \\
\text { ground levels through very } \\
\text { old and poorly abandoned } \\
\text { brine wells. }\end{array}$ & $\begin{array}{l}\text { Casing } \\
\text { overstretching due } \\
\text { to caverns } \\
\text { convergence }\end{array}$ & $\begin{array}{l}\text { A flaw in the casing at a } \\
440-m \text { depth, attributed } \\
\text { to poor welding job. }\end{array}$ \\
\hline \multirow[t]{3}{*}{$\begin{array}{l}\text { Impact at the } \\
\text { surface }\end{array}$} & Effects at ground level & $\begin{array}{l}\text { A dozen geysers, } \\
\text { gas }+ \text { brine, }\end{array}$ & $\begin{array}{l}\text { Oil seeps after } \\
\text { April } 12,2014\end{array}$ & $\begin{array}{l}\text { During first filling, } \\
10^{7} \mathrm{~m}^{3} \text { of gas migrate to } \\
\text { an aquifer layer, then to } \\
\text { ground level }\end{array}$ \\
\hline & Distance from wellhead & $13 \mathrm{~km}$ & $200 \mathrm{~m}$ & \\
\hline & Evacuation/Casualties & Two casualties & $\begin{array}{l}10 \text { cows put down; } \\
\text { one family } \\
\text { displaced for some } \\
\text { days }\end{array}$ & 30 residents evacuated \\
\hline \multirow[t]{2}{*}{$\begin{array}{l}\text { Emergency resp. } \\
\& \text { remediation }\end{array}$} & Measures taken & $\begin{array}{l}\text { Bottom plug set on } \\
\text { January } 24 \text {. A video } \\
\text { detects the breach. } \\
36 \text { shallow boreholes are } \\
\text { drilled, eight of them find } \\
\text { gas. A seismic reflection } \\
\text { survey is undertaken, }\end{array}$ & $\begin{array}{l}\text { Wellhead checks, } \\
\text { CBL, sonar survey, } \\
\text { measures taken for } \\
\text { water protection, } \\
\text { video, monitoring } \\
\text { wells }\end{array}$ & $\begin{array}{l}\text { A bottom plug is set. } 36 \\
\text { boreholes drilled to the } \\
\text { aquifer layer, } 17 \text { find gas. } \\
\text { Video. }\end{array}$ \\
\hline & Remediation & Rules rescinded & $\begin{array}{l}\text { An internal string } \\
\text { is set }\end{array}$ & Caverns filled with brine \\
\hline
\end{tabular}


Table 3. The main characteristics of Eminence, Mississipi; Teutschenthal, Germany; Boling, Texas; Clute, Texas.

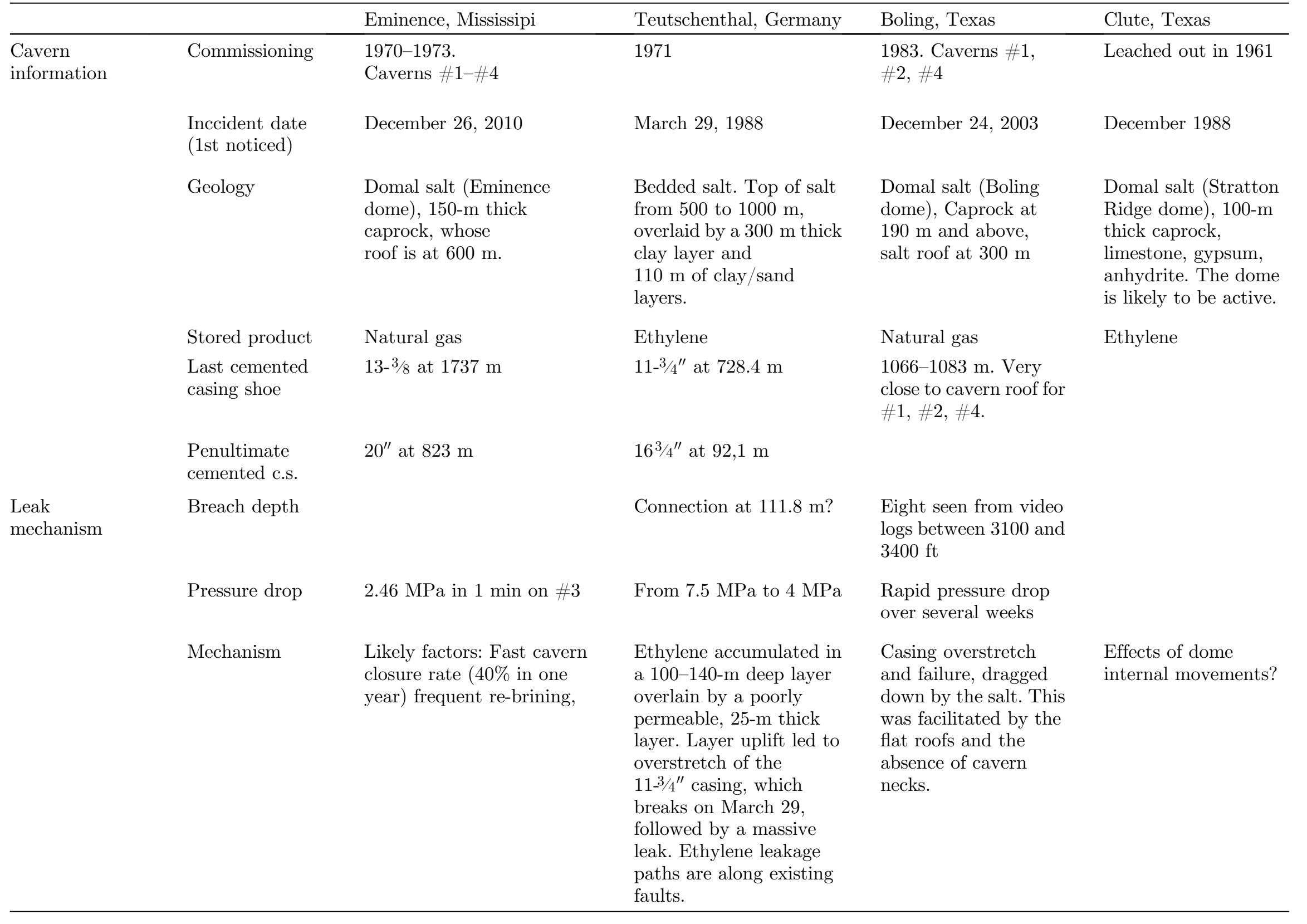


Table 3. (Continued).

\begin{tabular}{|c|c|c|c|c|c|}
\hline & & Eminence, Mississipi & Teutschenthal, Germany & Boling, Texas & Clute, Texas \\
\hline \multirow[t]{3}{*}{$\begin{array}{l}\text { Impact at } \\
\text { the surface }\end{array}$} & $\begin{array}{l}\text { Effects at } \\
\text { ground level }\end{array}$ & $\begin{array}{l}\text { Blow-outs in shallow } \\
\text { boreholes }\end{array}$ & $\begin{array}{l}\text { One hour after the } \\
\text { pressure drop, first } \\
\text { ethylene + water blow- } \\
\text { out, followed by several } \\
\text { others, gas production } \\
\text { during several days, } 60 \% \\
\text { to } 80 \% \text { of cavern volume } \\
\text { is lost. Blow-out spots } \\
\text { aligned on parallel lines. } \\
\text { Ground uplift by } 1.5 \mathrm{~m} \\
\text { before the eruption. } \\
\text { Fractures at ground } \\
\text { level. }\end{array}$ & None & $\begin{array}{l}\text { None. Gas loss } \\
\text { estimated to be } \\
27000 \mathrm{~m}^{3} \text { on } \\
\text { December } 30 .\end{array}$ \\
\hline & $\begin{array}{l}\text { Distance from } \\
\text { wellhead }\end{array}$ & $\begin{array}{l}\text { The leak escaped from the } \\
\text { ground around } \# 1 \text { wellhead }\end{array}$ & $50 \mathrm{~m}-250 \mathrm{~m}$ & & \\
\hline & $\begin{array}{l}\text { Evacuation/ } \\
\text { Casualties }\end{array}$ & $\begin{array}{l}\text { Twenty families during two } \\
\text { weeks }\end{array}$ & An $8 \mathrm{~km}^{2}$ zone & & \\
\hline \multirow[t]{2}{*}{$\begin{array}{l}\text { Emergency resp. } \\
\text { and remediation }\end{array}$} & Measures taken & $\begin{array}{l}\text { Partial venting } 245 \text { shallow } \\
\text { boreholes drilled } 13 \\
\text { boreholes drilled to the } \\
\text { caprock }\end{array}$ & $\begin{array}{l}\text { Ethylene dilution was } \\
\text { swift. Alignment of } \\
\text { blow-out spots was } \\
\text { checked through aerial } \\
\text { photos. }\end{array}$ & $\begin{array}{l}\text { Cold spots detected } \\
\text { above the casing shoe } \\
\text { by temperature logs. } \\
\text { Video inspection. }\end{array}$ & $\begin{array}{l}\text { After discussion with } \\
\text { the mining } \\
\text { authorities, a new } \\
\text { borehole was drilled, } \\
\text { encountering gas on } \\
\text { March 19, 1990. Gas } \\
\text { was vented. }\end{array}$ \\
\hline & Remediation & $\begin{array}{l}\text { The four caverns are } \\
\text { abandoned }\end{array}$ & $\begin{array}{l}\text { An } 8-5 / 8^{\prime \prime} \text { string is set in } \\
\text { the casing and the } \\
\text { annular space is } \\
\text { monitored. }\end{array}$ & $\begin{array}{l}\text { Milling of the } 11-3 / 4^{\prime \prime} \\
\text { casing on a } 30-\mathrm{m} \\
\text { length, a } 10-3 / 4^{\prime \prime} \text { string } \\
\text { is set in the casing. }\end{array}$ & Unknown \\
\hline
\end{tabular}




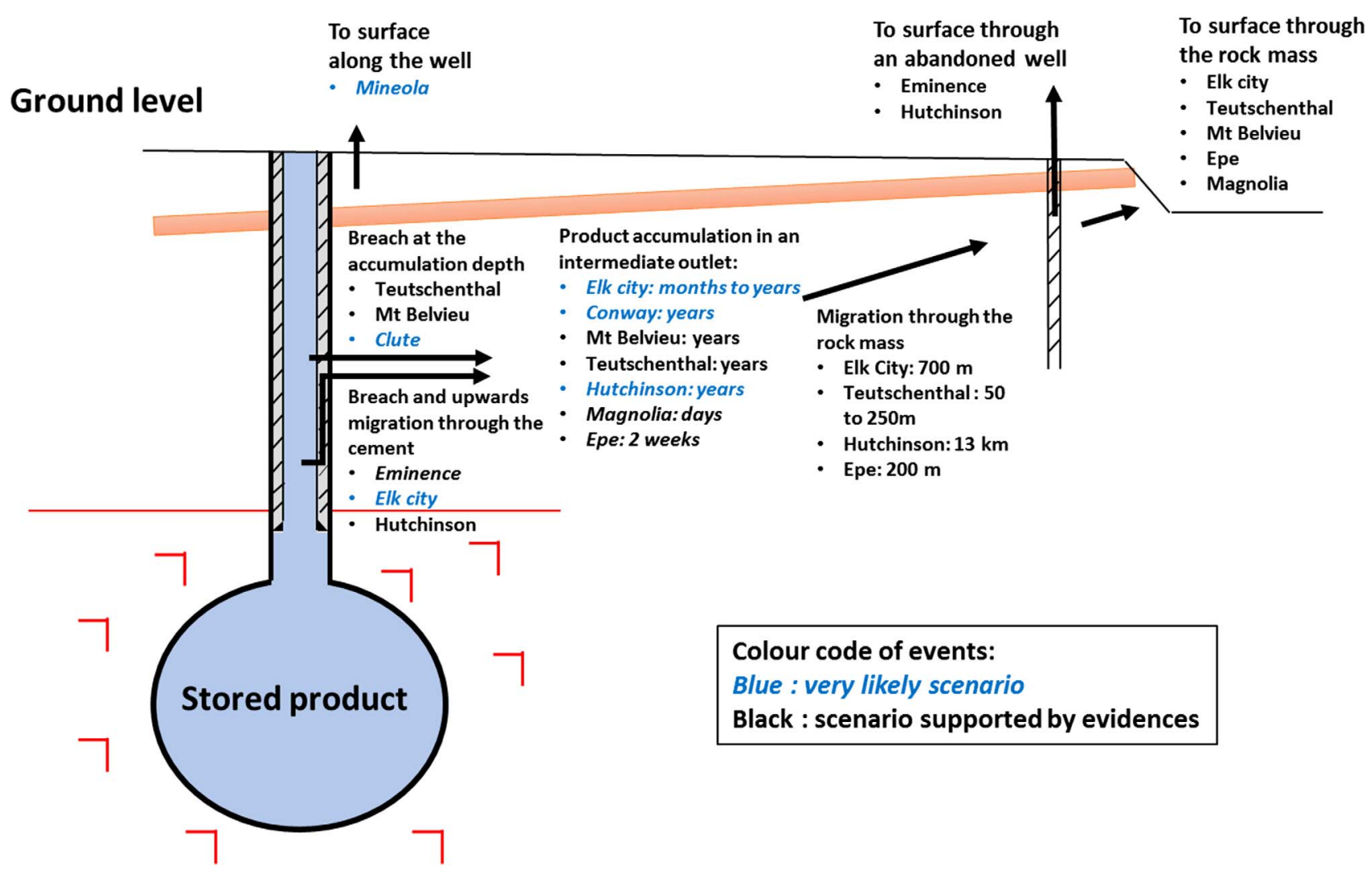

Fig. 13. Schematic of leakage development cases with an intermediate outlet accumulation.

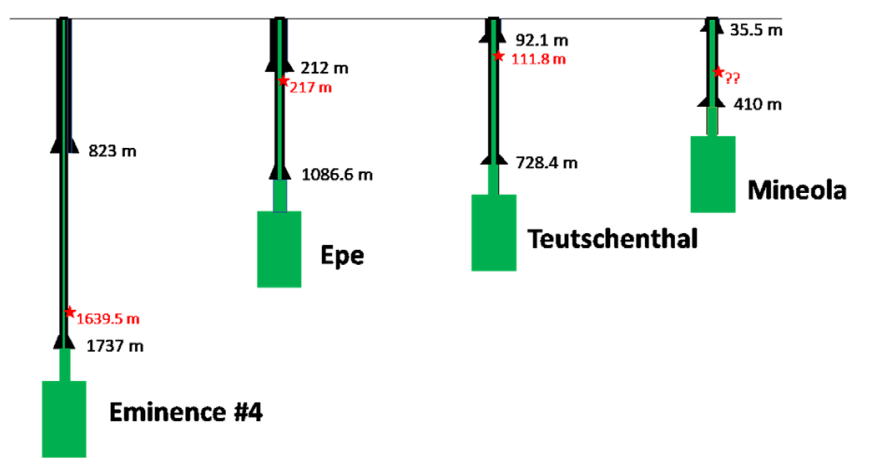

Fig. 14. Depths of the two last cemented casings and depth of the breach through the tubing at Eminence, Epe, Teutschenthal and Mineola.

exhibits very favourable properties; however, it does not mean that no fluid can migrate at the rocksalt-cement-steel interfaces, as witnessed in the Eminence or Boling examples. We also note here that cases exist in both the storage industry and in oil and gas production wells, where a leak built up in the cemented annulus.

Generally speaking, however, in spite of many advances (see Sect. 1), it is difficult to guarantee cementation quality from wellhead to the last cemented casing shoe.
In many cases, the leak finds an underground receptor, i.e., a porous and permeable zone whose volume is large enough to accommodate, at least for a period of time, a large quantity of fugitive hydrocarbons. This outlet can be at the same depth as the breach, for instance in the dome caprock (Mont Belvieu, and probably Clute also) or, as in Teutschenthal, in a sandstone layer, $30 \mathrm{~m}$ thick, below a tight overburden layer.

However, in many other cases, receptor depth, where leaking products accumulate, is shallower than the breach depth itself. When the enclosing rock is tight and well cementation is poor, hydrocarbons can migrate upward in the cemented annulus between the steel casing and the rock, until it encounters a permeable layer: at Hutchinson, the point of escape and lateral migration was a thin, fractured dolomitic horizon between two tight shale layers, into which the gas migrated and moved updip, toward the town.

In most cases there is an accumulation phase during which the escaped product progressively fills the receptor: pressure increases to reach equilibrium with cavern pressure. The products may remain in the outlet for a long period (Boling, Eminence where Cavern \#7 leaks to the caprock); or product pressure may build up to a level such that a pathway is created to ground level (the outlet is the Doxey shales at Elk City; and the brine aquifer at salt top in the Conway case).

A poorly consolidated caprock above a salt dome, composed of insoluble blocks left by dissolution (of evaporitic 
Table 4. Well ages in hydrocarbon storage leakage events.

\begin{tabular}{|c|c|c|c|c|}
\hline Site & $\begin{array}{l}\text { Date drilled } \\
\text { (or debrined) }\end{array}$ & Incident date & $\begin{array}{l}\text { Time span between } \\
\text { creation and } \\
\text { accident }\end{array}$ & Comment \\
\hline $\begin{array}{l}\text { Elk City, } \\
\text { Oklahoma }\end{array}$ & $\begin{array}{l}\text { Unknown. After } \\
1954 ? ?\end{array}$ & February 23, 1973 & 19 years? & $\begin{array}{l}\text { Leak likely started as early as } \\
\text { November } 1972\end{array}$ \\
\hline Conway, Kansas & Beginning 1951 & After 1956 & 5-60 years & The described accident in 2012 \\
\hline Yoder, Kansas & - Idem & June 30,1980 & 30 years or more & \\
\hline $\begin{array}{l}\text { Mont Belvieu, } \\
\text { Texas }\end{array}$ & 1963 & $\begin{array}{l}\text { September 17, } 1980 \\
\text { (wellhead pressure } \\
\text { drop) }\end{array}$ & 17 years & October 3, 1980 (fire) \\
\hline Mineola, Texas & End of 1950's & $2000 ?$ & 50 years & Paper written in 2001 \\
\hline $\begin{array}{l}\text { Hutchinson, } \\
\text { Kansas }\end{array}$ & $\begin{array}{l}\text { Drilled in } 1980 \\
\text { Re-drilled in } 1990\end{array}$ & January 19, 2001 & 20 years & \\
\hline Epe, Germany & 1980 & February 23, 2014 & 34 years & \\
\hline $\begin{array}{l}\text { Magnolia, } \\
\text { Louisiana }\end{array}$ & 1970's & December 24, 2003 & 33 years & 6 weeks after repressurization \\
\hline $\begin{array}{l}\text { Eminence, } \\
\text { Mississippi }\end{array}$ & $1970-1973$ & 26 December 2010 & $37-40$ years & \\
\hline Teutschenthal & 1971 & March 29, 1988 & c. 17 years & \\
\hline $\begin{array}{l}\text { Boling, } \\
\text { Texas }\end{array}$ & $\begin{array}{l}\text { End of January } \\
1983 \text { (de-brined) }\end{array}$ & Fall 2005 & c. 22 years & \\
\hline Clute, Texas & $\begin{array}{l}\text { Leached out in } \\
1961\end{array}$ & December 1988 & c. 27 years & \\
\hline
\end{tabular}

minerals), is favourable to the development of a leak, on the one hand because it is the site of differential displacements in the casing (Sect. 3.1) and, on the other hand, because the caprock is per se a possible outlet. Revision of regulations in Texas took this fact into account. One might infer that leaks should be more frequent associated with salt dome storages rather than those in bedded salts.

In fact, among the 12 cases presented above, 7 are related to domal salts and 5 with bedded salt. Both cases are found in sedimentary environment, in which successions of tight and permeable layers commonly occur in the overburden. Mudstones and fine-grained siltstone interbeds are also found within massively bedded halite deposits. Therefore, above a bedded salt formation, as above a salt dome, intermediate aquifer layers (or, at least, more permeable layers, as in the Hutchinson case or at Elk City) overlain by a tighter overburden (Teutschenthal) are potential candidates for hosting an accumulation of leaking hydrocarbons. In addition, in a salt dome, the overburden has been deformed, which can aid fracture enhanced pathway development within the overburden succession; the caprock often is porous and permeable, making drilling and cementing a more difficult job.

\subsubsection{A pressure differential is needed (leakage driving force)}

In addition to a breach in the casing and a receptor horizon, development of a significant leak requires a driving force, i.e., a pressure differential. At any depth, except maybe in the case of a natural gas storage when inventory is at a minimum, pressure of the stored product is larger than pore pressure in the rock mass (Fig. 15). The second condition for leak development, that of a pressure gradient driving the leakage flow, is always fulfilled. Density of the stored product plays a major role: the lighter the fluid, the larger the pressure differential between products pressure in the well and ground water pressure at leak depth; it is larger when the cavern is deeper and breach is shallower. This is especially true in the case of natural gas: when the cavern is full and gas pressure is at a maximum, it is higher than geostatic pressure at almost any depth above the casing shoe (Fig. 16); when a leak through a breach is created, it can find its way to ground level even through low permeability layers. Density also plays a role when considering effects at ground level, see below.

When leaking product migrates through the cemented annulus before reaching an outlet, pressure differential must 


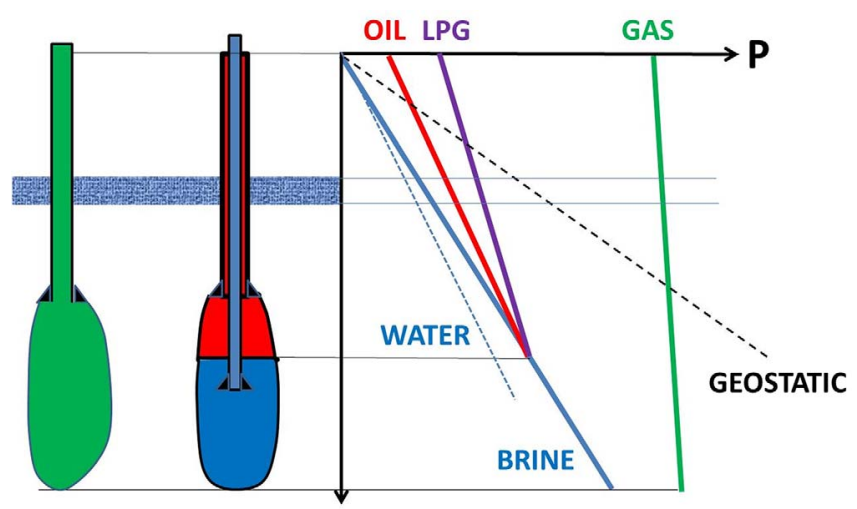

Fig. 15. Pressure distribution in the borehole in the case of a natural gas storage (green line) and in the case of an LPG or oil caverns (purple and red lines, respectively). Geostatic pressure and typical water pressure in aquifer layers are also represented.

be computed at receptor depth, where it is higher than at breach depth. At Hutchinson, on January 14, 2001, gas pressure was $4.76 \mathrm{MPa}$ at casing shoe depth $(238 \mathrm{~m})$ and only slightly lower (hence, larger than geostatic) at the depth of the fractured layer through which gas escaped and spread, allowing fast leak rates.

\subsubsection{Wellhead pressure drops}

In several occurrences (Epe, Teutschenthal, Eminence, Boling, Mont Belvieu and Hutchinson), a pressure drop was observed at the wellhead:

- Epe (an oil storage), wellhead pressure dropped by $0.36 \mathrm{MPa} 3$ weeks before oil appeared at ground surface.

- Teutschenthal (an ethylene storage), pressure dropped from 7.5 MPa to $4 \mathrm{MPa}$ : and ethylene blew out at ground level $1 \mathrm{~h}$ later.

- Eminence (a natural gas storage), pressure dropped by $2.56 \mathrm{MPa}$ in $1 \mathrm{~min}$.

- Boling (a natural gas storage), pressure drop was spread over one week, although natural gas did not appear at ground level and it is likely that gas found a porous and permeable level in the salt overburden.

- Mont Belvieu (an LPG storage) pressure dropped 20 days before an explosion occurred at ground surface.

- At Hutchinson (natural gas) the pressure dropped by $0.7 \mathrm{MPa}$ follows the first blow-out after $15 \mathrm{~min}$; the salty aquifer layer below the city of Hutchinson was an intermediate outlet in which gas accumulated and the pressure drop generated by the blow-out took $15 \mathrm{~min}$ to propagate to the $\mathrm{S} 1$ cavern, $13 \mathrm{~km}$ away.

No pressure drop is mentioned in other cases of Section 2, but one was also observed in Regina South Gas Storage Cavern No. 5 in Saskatchewan. The volume of this cavern, leached out in 1983-1984, was more than 700000 bbls $\left(45000 \mathrm{~m}^{3}\right)$.

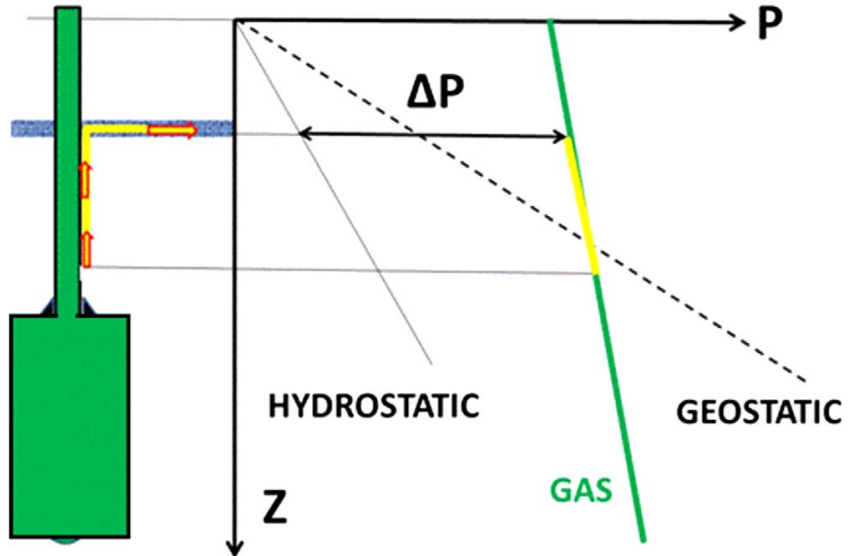

Fig. 16. A gas leaks from a breach in the casing. Gas migrates through the cement and reaches a shallower aquifer layer, at which point its pressure is much higher than in situ groundwater pressure and even, in many cases, higher than geostatic pressure.

"Maximum pressure was 3000 psi (20.5 MPa), a relatively low value for a cavern whose roof depth was $5363 \mathrm{ft}(1780 \mathrm{~m})$. Roof salt thickness was $50 \mathrm{ft}$. The final developed roof position was higher than originally planned and located in a structurally unstable area with many thin insoluble bands. In July 1989 , a 267-psig pressure drop occurred in this cavern following gas fill up to 3000 psig. A rate of change in pressure decline from the pressure vs. time graphs used to monitor cavern operating condition suggested the cavern roof had a leak away from the well bore (Crossley, 1998).'"

A block fall generates no perennial gas pressure change; the pressure drop must be due to a gas leak to a porous and permeable layer above the salt roof.

Occurrence of a rapid pressure drop is especially puzzling in the case of a natural gas storage cavern. Gases are much more compressible than liquids and a large gas pressure drop requires the loss of a large fraction of the cavern inventory. When $V$ is the cavern volume, the pressure drop due to a $\Delta V$ inventory loss is $\Delta P=\Delta V / \beta V$ where $\beta$ is the factor of compressibility of the fluid-filled cavern (Bérest et al., 1999); for a brine cavern, $\beta=4 \times 10^{-4} /$ $\mathrm{MPa}$; for a propane filled cavern, $\beta=10^{-3} / \mathrm{MPa}$; for a gas-filled cavern, $\beta=1 / P$ where $P$ is gas pressure, for instance $\beta=10^{-1} / \mathrm{MPa}$ when gas pressure is $10 \mathrm{MPa}$. A $\Delta P=0.5 \mathrm{MPa}$ pressure drop is generated by a $0.125 \%$ inventory loss in a brine cavern; in a gas cavern, the same pressure drop is generated by a $5 \%$ inventory loss - a huge value. For this reason, a large pressure drop in a gas cavern is possible only when the casing breach opens in a large, porous and permeable volume (Mont Belvieu); or, long after the breach is created, when the leaking gas reaches ground level or a large porous and permeable receptor. At Hutchinson, the pressure drop was observed 15 min after gas erupted in downtown Mont Belvieu - the time needed for 
the pressure drop in the salty aquifer below Mont Belvieu to propagate to the cavern breach.

\subsubsection{Products viscosity, capillary effects}

Leakage can affect all types of stored fluids, oil, natural gas, ethylene or LPG. A low viscosity and a low entry pressure in the rock formation favours leakage; as such, natural gas (and, a fortiori, hydrogen) may be more likely to leak than liquids. It is difficult to quantify how much more likely to leakage natural gas is as leak rate depends, in addition to gas viscosity, on the way a leak path develops. Leak flow is likely to be bi-phasic first, with a gas-water front inside which capillary pressures slow down gas migration rate, before a continuous path is created from breach to ground level or to an intermediate receptor. The storage industry (Crotogino, 1996) suggested empirical rules for conversion of a gas leak (which can be easily measured during a tightness test) into a liquid leak. Cases have been observed in which the cavern is found to be somewhat leaky when the testing fluid is a gas, but tight when it contains a liquid hydrocarbon. An example was at Magnolia, where the cavern did not pass a Nitrogen Mechanical Integrity Test, although the cavern had experienced no leakage issue when the annular space was filled with a much more viscous diesel oil (Bennett, 2009).

\subsection{Eruption at ground level}

\subsubsection{The path toward ground level}

One might think that a leak necessarily appears at ground level near the wellhead, i.e., it follows the shortest path to surface. This was clearly the case at Mineola, from which it was inferred that the breach was shallow (the shoe of the penultimate casing was only 35.5-m deep) and at Eminence in 2011. However, in the general case, and especially when hydrocarbons accumulate first in an intermediate receptor (a porous layer or caprock, e.g., Hutchinson, Teutschenthal, Clute, Elk City, Epe) the path found by the leak can be complex and surface release somewhat distant; it is often governed by geological features at shallow depth and is not always the shallowest path along a vertical line. In such a case, the blow-out can occur abruptly (Hutchinson, Elk City, Teutschenthal) and can be localized at a large horizontal distance from the wellhead (600 m at Elk City, 50-200 m at Teutschenthal, $500 \mathrm{~m}$ at Epe, and even up to $14 \mathrm{~km}$ in the exceptional case of Hutchinson); and, probably at a point where elevation is low (Mont Belvieu, Elk City).

At Hutchinson, general opinion is that a period of 8 years was needed for gas to charge a thin, 13-km long subhorizontal fractured level before gas erupted in downtown Hutchinson (several experts believe that filling took place over a few days prior to the eruptions, however, this conclusion is not fully substantiated by the (scarce) available information). At Teutschenthal, two distinct steps were observed: first, gas slowly filled an aquifer at 100-m-140-m depth, generating an uplift, and opening a new breach in the severely stretched casing. This led to a significantly increased leak rate, a pressure drop (from 7.5 MPa to $4 \mathrm{MPa}$ ) in the cavern and, $1 \mathrm{~h}$ later, a blow-out at ground level. Both the cavern and the intermediate receptor were vented by gas outflow at ground level, with ground uplift vanishing.

\subsubsection{Effects at ground level}

The effects observed at ground level depend on many factors, among which are the nature of the stored gas, the configuration of shallow layers, and local topography. Two types of effects can be observed: mechanical effects in case of an abrupt blow-out (Teutschenthal, or Elk City, where 30-tons rock blocks were uplifted; Yoder where, however, the propane/water jet was small) and chemical effects (Mont Belvieu, where the gas exploded; Hutchinson, where several explosions occurred). Importantly, no asphyxia case has been reported in the incidents discussed here. It is known from other types of incidents (wellhead failures, which often lead to a loss of the full cavern inventory e.g., Moss Bluff) that a natural gas blow-out, with high gas flow rates (gas velocity is sonic at ground level) is not an extremely severe hazard (except at the very beginning of the process) as natural gas, lighter than air does not spread laterally at ground level. In contrast, oil, and more generally liquids, remain at ground level and generate low-rate leaks (Epe), and do not burn in the absence of an ignition source. This may not be true when hydrocarbons spread over a large area of ground, as, above the liquid phase, a cloud forms containing the most volatile parts, ignition of which is easier. Ethylene, which is stored in a supercritical form, is gaseous at atmospheric pressure; its density is close to that of air, with which it forms an explosive mixture (however ethylene decomposes under the effect of light). At Clute, ethylene remained confined in the caprock. At Teutschenthal, it appeared haphazardly at ground level, however, topography and wind favoured dispersal. LPGs present a more difficult problem. In the cavern, they are liquid, but vaporize, at least partially, on their way to ground level when their pressure becomes lower than their vaporization pressure - at least when the flowrate is not too fast, and enough time is left for the rock mass to provide the heat needed for phase change. In their gaseous state, they are heavier than air (propane relative density is 1.5) and, at ground level, they tend to remain stagnant at low elevation points, or in building foundations (Mont Belvieu, Elk City). At Elk City effects of the blowout were mechanical rather than chemical; measurements proved that gas concentration at ground level was small (less than 1\%).

\subsubsection{Actions taken after a leak is found}

After the occurrence of a leak is established, its origin must be confirmed (it could result from a breach in a buried pipeline). Gas composition often is a clue. Drilling boreholes to shallow ground water level, or to the level where products circulate, allows venting the gas and understanding the pathways followed by the leak (at Hutchinson, gas underground pathways, which were complex, were identified progressively; it was composed of several branches through which gas flowed toward the city). 
When the leaking cavern is identified, it must be vented, when possible. At Boling, a temperature log identified the depth at which the leak took place, as gas depressurization creates a cold spot. Frequently, a plug is set in the wellbore, as deep as possible and hopefully below the leak level. A video log often assists in detecting this level, especially when the rupture was created by excessive tension on the cemented casing, or re-entry operations during well conversion damaged the casing (Hutchinson).

\section{General lessons learned from case analysis for well monitoring}

\subsection{Pressure monitoring}

Pressure monitoring at cavern wellhead is necessary; at Mont Belvieu, this monitoring provided a warning, 15 days before the blow-out. However, in most cases a pressure drop was not observed, or was observed too late, or even observed after the blow-out (Hutchinson), when the leak path was already fully developed. In principle, careful monitoring of the wellhead pressure over a long period should provide a warning; however, in a natural gas storage, the stored product is so compressible that pressure changes resulting from a leak are exceedingly small, especially when the cavern experiences frequent injection/withdrawal, the cumulative effects of which generate large uncertainties. In a strategic oil storage, the inventory of which changes little, a better resolution can be anticipated but important efforts must be made, in terms of accuracy and interpretation, to reach an acceptable resolution (Colcombet and Nguyen, 2013).

\subsection{Well completion}

The role of wellbore completion is extremely important. It was observed that the combination of a flat cavern roof and a short chimney leads to tensional stresses and stretching of the casing, especially when cavern creep closure is fast. In many of the described cases, a large difference can be observed between the depth of the deepest and penultimate cemented casing. In other words, between the shoes of these two casings, a single "barrier" (i.e., a casing cemented to the rock formation) can be found: a breach through the steel casing opens directly to the rock mass. It is interesting to note that, in most cases, when repairing a leak, an inner steel tube is added to form, with the preexisting casing, an annular space the bottom to which is closed; this annulus is filled with water whose pressure is monitored at ground level - a way of creating a "second barrier" which did not exist in the initial design. Such a completion (an internal tube delimiting a monitoring annulus plugged at its bottom) has been mandatory in France and Germany for natural gas storages and the trend in Europe is to equip new liquid storage caverns with such a system (it is a requirement under Dutch mining law, Koopmans et al., 2014). For many years in Texas, Louisiana and Kansas (three states in which can be found the majority of US salt cavern storages), State regulation has required that new caverns have two cemented casings, anchored in the salt formation.
In addition, a tightness test is mandatory at least every 5 years, which covers the case of old caverns which are not equipped with a double casing.

\subsection{Mechanical Integrity Tests (MITs)}

Although the number of storage caverns in operation increases, fewer and fewer accidents are occurring. Several reasons exist for this. Recent caverns are equipped with a double casing anchored to the salt formations, or a water/brine-filled annular space. Both new and old caverns are now tested using the Nitrogen Leak Test (NLT) and Liquid Leak Test (LLT) methods. The former consists of injecting nitrogen into the annular space, the latter instead of nitrogen, a liquid hydrocarbon is injected. Salt caverns present a remarkable advantage (when compared to depleted reservoirs or, more generally, oil and gas fields): borehole tightness can be tested, as the borehole opens in a closed "container" (the cavern itself), which is almost perfectly tight. Typically, the NLT consists of injecting nitrogen into the annular space slightly below the last cemented casing shoe. A logging tool is used to measure the brine/nitrogen interface location. At least two measurements, generally separated by 3 days, are undertaken. Upward movement of the interface is deemed to indicate a nitrogen leak. Pressures are measured at ground level, and temperature logs are recorded to allow estimating effects such as thermal expansion and compressibility and enable precise back-calculation of nitrogen seepage. MITs are mandatory every five years in most US states and countries. Fail/Pass criteria have been proposed by the SMRI (Crotogino, 1996). Space does not permit expanding on these notions here, but MITs - and especially NLTs - are the most significant prevention tool in the cavern industry.

\section{Conclusion}

In this paper, based on a study funded by the SMRI, 12 incidents involving product leaks through the cemented casing of salt storage cavern wells are described. Their causes have been analyzed and general lessons drawn, which are informative for not only storage caverns, but also oil and gas field wells. They prove that experience, dissemination of new techniques and best practices, and advances in well design (double casing) and testing (MITs), leads to an ongoing reduction in the frequency and severity of incidents.

Acknowledgments. Most examples described in this paper were collated and described during the cooperative research program RR-2017-1 funded by the SMRI. The authors are indebted to the members of the SMRI and to Yvan Charnavel (Storengy), SMRI project sponsor, whose comments helped improve the manuscript. Reviewers' comments were extremely helpful. The Research Report is available through https://www.solutionmining.org.

Analysis of the incidents in this paper was in part funded by the French Agence Nationale de la Recherche (ANR) in support of the FluidStory Project devoted to storage of $\mathrm{O}_{2}$ and $\mathrm{CO}_{2}$ in salt caverns. This project includes researchers from Armines, Areva- $\mathrm{H}_{2}$ Gen, BRGM, Brouard Consulting, Geostock, Geogreen and Ecole Polytechnique. DJE acknowledges support from the 
EPSRC-funded IMAGES project and publishes by permission of the Director, British Geological Survey.

\section{References}

Allen K. (1971) Eminence- natural gas storage in salt comes of age, Am. Inst. Min. Metall. Eng. Trans. 250, 276-279.

Allen K. (1972) Eminence dome - Natural gas storage in salt comes of age, J. Pet. Technol. 24, 1299-1301.

Allison M.L. (2001) Hutchinson, Kansas; A geological detective story, Geotimes. https://www.agiweb.org.

Arnold C., Hanisch P., Pischner M. (2010) Long term development and extension of brine field and storage site Teutschenthal Bad Lauchstaedt in Central Germany, Proc. SMRI Fall Conference Leipzi, pp. 137-154.

Baar C.A. (1977) Applied salt-rock mechanics, 1 developments in geotechnical engineering, Vol. 16-A, Elsevier Science, Amsterdam, pp. 143-147.

Bennett W. (2009) Letter to Mr Joe S. Ball, Injection and Mining Division, Office of Conservation, Louisiana Department of Natural Resources, from Gulf South, dated November 10th 2009, requesting an extension to 2009 requirement for plugging and abandoning Gulf South Well \#1, 2 p.

Bérest P., Bergues J., Brouard B. (1999) Static and dynamic compressibility of deep underground caverns, Int. J. Rock Mech. Min. Sci. 36, 1031-1049.

Bérest P., Brouard B. (2003) Safety of salt caverns used for underground storage, Oil Gas Sci. Technol. - Rev. IFP Energies nouvelles 58, 361-384.

Bezirksregierung Arnsberg (2014), http://www.bezregarnsberg. nrw.de/themen/o/oelschaden_gronau/fragen_antworten/ index.php) (in German).

Bryson W.R. (1980) Leakage of liquefied petroleum gas from storage projects in bedded salt - An update, Proc. SMRI Fall Meeting, Minneapolis, Minnesota.

California Council on Science and Technology (2018) Long-term viability of underground natural gas storage in California: An independent review of scientific and technical information. Report prepared by the California Council on Science and Technology (CCST), 913 p. https://ccst.us/publications/ 2018/2018NGS.php.

Coates G.K., Lee C.A., McClain W.C., Senseny P.E. (1981) Failure of man-made cavities in salt and surface subsidence due to sulfur mining, Topical Report RSI-0131, Submitted to Strategic Petroleum Reserve, Geotechnical Division, Sandia National Laboratories, Albuquerque, NM 87185, 136 p.

Colcombet B., Nguyen H.D. (2013) Well integrity management at the Geosel Manosque storage facility, Proc. SMRI Fall Meeting, Avignon, pp. 221-230.

Coldewey W.G., Wesche D. (2015) Zusammenfassende Betrachtung der durchgeführten Untersuchungen sowie der geplanten Sanierungsmaßnahmen des Rohölschadens an der Kaverne S5 der Salzgewinnungsgesellschaft Westfalen mbH in Gronau-Epe unter besonderer Berücksichtigung der Geologie und Hydrogeologie, Bezirksregierung Arnsberg, 6 p. http://www.bezregarnsberg.nrw.de/themen/o/oelschaden_gronau (in German).

Crossley N.G. (1998) Sonar surveys used in gas-storage cavern analysis, Oil Gas J. 96, 18 p.

Crotogino F. (1996) SMRI Reference for external well mechanical integrity testing/performance, data evaluation and assessment. Summary of the SMRI research project report, Proc. SMRI Spring Meeting Houston, Texas, USA.
Edgar (2005) Notes to unaudited condensed consolidated financial statements. http://sec.edgar-online.com/2005/05/05/ 0001262943-05-000014/Section6.asp.

EIA (2006) U.S. underground natural gas storage developments: 1998-2005, Energy Information Administration (EIA), Office of Oil and Gas, October 2006, 16 p.

Evans D.J. (2007) An appraisal of underground gas storage technologies and incidents, for the development of risk assessment methodology, Report by the British Geological Survey to the Health and Safety Executive, BGS Open File Report Series, OR/07/023, 2 volumes.

Fay (1973a) The Elk city blow-out, Oklahoma Geol. Notes 33, April, 2.

Fay (1973b) The Elk city blow-out - A chronology and analysis, Oklahoma Geol. Notes 33, August, 4.

Gebhardt F., Eby D., Barnett D. (2001) Utilizing coiled tubing technology to control a liquid propane storage well fire, a case history, Proc. SMRI Spring Meeting, Orlando, Florida, pp. 301-306.

Hopper J.M. (2004) Gas storage and single-point failure risk, Natural Gas, Energy Markets, Hart Energy Publishing, Houston, TX, USA, 4 p. http://www.shalepropertyrights.com/blog/ wp-content/uploads/2013/03/article_singlepointfailurerisk.pdf.

Johnson W. (2002) KDHE unveils gas storage rules, Hutchinson News, July 28.

Johnson C., Hoffine S. (2004) Update on fugitive NGL issues in the Conway area - Assessment and monitoring, Proc. SMRI Spring Meeting, Wichita, Kansas, pp. 199-226.

Kansas Geological Survey Web Site (2001) Hutchinson Response Project. https://www.kgs.ukans.edu/Hydro/Hutch/ GeneralGeology/index.html and https://www.kgs.ukans.edu/ Hydro/Hutch/references.html.

Katzung G., Krull P., Kühn F. (1996) Die Havarie der UGS Sonde Lauchstädt 5 im Jahre 1988, Auswirkungen und geologische Bedingungen; Zeitschrift für Angewandte Geologie 42, 1, 19-26 (in German).

Koopmans T., Groenenberg R., Pinkse T. (2014) 21st century gas oil storage in Twente, The Netherlands. State-of-the art, multiple-barrier design based on a novel risk management approach, Proc. SMRI Fall Meeting, Groningen, The Netherlands, pp. 31-44.

Kukla P., Urai J. (2015) Ölaustritte an der Erdoberfläche infolge einer Leckage an der Verrohrung der Kavernenbohrung Epe S5; Zusammenfassender Bericht zu den Ursachen der Ölaustritte und deren Verbreitung, Bezirksregierung Arnsberg, 38 p. http://www.bezreg-arnsberg.nrw.de/themen/o/oelschaden_ gronau (in German).

Lord A.S., Rautman C.A., Looff K.M. (2006) Geologic Technical Assessment of the Stratton Ridge Salt Dome, Texas, for Potential Expansion of the U.S. Strategic Petroleum Reserve, Report prepared by Sandia National Laboratories, Report Number SAND2006-7159, 42 p. http://prod.sandia.gov/ techlib/access-control.cgi/2006/067159.pdf.

Marlow R.S. (1989) Cement bonding characteristics in gas wells, JPT, 1146-1153.

Miyazaki B. (2009) Well Integrity: An overlooked source of risk and liability for underground natural gas storage, in: Evans D.J., Chadwick R.A. (eds.), The Geological Society of London, pp. 162-172.

Nations J.D. (2005) Report to Arizona Oil and Gas Commission, Dec. 13th 2005 on safety at gas storage facilities, 5 p. http:// azogcc.az.gov/sites/azogcc.az.gov/files/meetings/2006.01.13. pdf. 
Nicot J. (2009) A survey of oil and gas wells in the Texas Gulf Coast, U.S.A., and implications for geological sequestration of $\mathrm{CO}_{2}$, Environ. Geol. 57, 1625-1638.

Osnes J.D., DeVries K.L., Ratigan J.L., Meece M.W., Thompson M., Spencer G.W. (2007) A case history of the threaded coupling production casing failure in gas caverns - Part 1: detection and geomechanical analysis, in Proc. SMRI Fall Meeting, Halifax, Nova Scotia, October 7-10, 29 p.

Pirkle R.J. (1986) Proceedings of the American Gas Association Meeting, Chicago, IL, April 1986.

Ratigan J. (2001) Testimony before the Kansas Senate Utilities Committee, Topeka, Kansas http://www.kgs.ku.edu/Hydro/ Hutch/GasStorage/ratigan.pdf.

Ratigan J. (2009) Liquefied petroleum gas storage at Mont Belvieu, Texas, USA, in: Sha Zuoliang (ed.), Proc. 9th World Salt Symposium, Gold Wall Press, Beijing, pp. 449-456.

Ratigan J., McClain A., Nichols J., Hoffine S. (2002) Fugitive NGL at the Williams midstream natural gas liquids Conway underground storage facility - Geologic and hydrogeologic studies, Cavern well testing and NGL recovery plans, Proc. SMRI Spring Meeting, Banff, Alberta, pp. 339-362.

Réveillère A., Bérest P., Evans D.J., Stöwer M., Chabannes C., Koopmans T., Bolt R. (2017) SMRI Research Report RR2017-2. Past salt caverns incidents database Part 1: Leakage, Overfilling and Blow-out, 124 p. https:// www.solutionmining.org.

Sobolik S.R., Ehgartner B.L. (2012)Analyzing large pressure changes on the stability of large-diameter caverns using the M-D model, in: Bérest P., Ghoreychi M., Hadj-Hassen F.,
Tijani M. (eds.), Proc. Mech. Beh. of Salt VII, Taylor \& Francis Group, London, pp. 321-329.

State of Louisiana (2007) Oil Insurance Limited versus Dow Chemical Company, Dow Hydrocarbons and Resources Inc., Frank's Casing Crew Rental Tools inc. and Grey Wolf Drilling Company, State of Louisiana Court of Appeal, First Circuit, 2007 CA 0418. Judgment Rendered, November 2nd, 2007, 10 p. http://www.la-fcca.org/Opinions/PUB2007\%5C200711/2007CA0418Nov2007.Pub.17.pdf.

Toth J. (1989a) Search ruled out for chemical lost in Clute, Houston Chronicle, Section: B, September 19, 1989, 1 p (subscription required).

Toth J. (1989b) Firm backtracks, plans to drill well to find missing ethylene, Houston Chronicle, September 21, 1989, 1 p. (subscription required)

Toth J. (1990) Gas is being burned off after mishap near Clute, Houston Chronicle, Section: A, April 7, 1990, 1 p. (subscription required)

Warren J.K. (2006) Evaporites: Sediments resources and hydrocarbons, Springer-Verlag, Berlin Heidelberg, Chapter 12, 935 p.

Watson T.L., Bachu S. (2007) Evaluation of the potential for gas and $\mathrm{CO}_{2}$ leakage along wellbores, SPE Paper 106817, SPE Drill. Complet. 24, 1, 115-126.

Wellinghoff J., Moeller P.D., Norris J.R., LaFleur C.A., Clark T.T. (2013) Order approving abandonment, amending certificate authority, and granting clarification, United States of America Federal Energy Regulatory Commission (FERC) decision relating to Transcontinental Gas Pipe Line Company. 